\title{
Validation of Aura MLS retrievals of temperature, water vapour and ozone in the upper troposphere and lower-middle stratosphere over the Tibetan Plateau during boreal summer
}

\author{
Xiaolu Yan ${ }^{1, a, b}$, Jonathon S. Wright ${ }^{2}$, Xiangdong Zheng ${ }^{1}$, Nathaniel J. Livesey ${ }^{3}$, Holger Vömel ${ }^{4}$, and Xiuji Zhou ${ }^{1}$ \\ ${ }^{1}$ Chinese Academy of Meteorological Sciences, Beijing, China \\ ${ }^{2}$ Center for Earth System Science, Tsinghua University, Beijing, China \\ ${ }^{3}$ Jet Propulsion Laboratory, California Institute of Technology, Pasadena, California, USA \\ ${ }^{4}$ Earth Observing Laboratory, National Center for Atmospheric Research, Boulder, Colorado, USA \\ a now at: Key Laboratory of Middle Atmosphere and Global Environment Observation (LAGEO), Institute of Atmospheric \\ Physics, Chinese Academy of Sciences, Beijing, China \\ b now at: Institute for Energy and Climate Research: Stratosphere (IEK-7), Forschungszentrum Jülich, Jülich, Germany
}

Correspondence to: Jonathon S. Wright (jswright@tsinghua.edu.cn) and Xiangdong Zheng (zhengxd@cams.cma.gov.cn)

Received: 19 December 2015 - Published in Atmos. Meas. Tech. Discuss.: 18 January 2016

Revised: 29 June 2016 - Accepted: 21 June 2016 - Published: 3 August 2016

\begin{abstract}
We validate Aura Microwave Limb Sounder (MLS) version 3 (v3) and version 4 (v4) retrievals of summertime temperature, water vapour and ozone in the upper troposphere and lower-middle stratosphere (UTLS; 10$316 \mathrm{hPa}$ ) against balloon soundings collected during the Study of Ozone, Aerosols and Radiation over the Tibetan Plateau (SOAR-TP). Mean v3 and v4 profiles of temperature, water vapour and ozone in this region during the measurement campaigns are almost identical through most of the stratosphere $(10-68 \mathrm{hPa})$, but differ in several respects in the upper troposphere and tropopause layer. Differences in v4 relative to $\mathrm{v} 3$ include slightly colder mean temperatures from 100 to $316 \mathrm{hPa}$, smaller mean water vapour mixing ratios in the upper troposphere $(215-316 \mathrm{hPa})$ and a more vertically homogeneous profile of mean ozone mixing ratios below the climatological tropopause $(100-316 \mathrm{hPa})$. These changes substantially improve agreement between ozonesondes and MLS ozone retrievals in the upper troposphere, but slightly worsen existing cold and dry biases at these levels.

Aura MLS temperature profiles contain significant cold biases relative to collocated temperature measurements in several layers of the lower-middle stratosphere and in the upper troposphere. MLS retrievals of water vapour volume mixing ratio generally compare well with collocated measurements, excepting a substantial dry bias $(-32 \pm 11 \%$ in v4) that ex-
\end{abstract}

tends through most of the upper troposphere (121-261 hPa). MLS retrievals of ozone volume mixing ratio are biased high relative to collocated ozonesondes in the stratosphere (18$83 \mathrm{hPa}$ ), but are biased low at $100 \mathrm{hPa}$. The largest relative biases in ozone retrievals (approximately $+70 \%$ ) are located at $83 \mathrm{hPa}$. MLS v4 offers substantial benefits relative to v3, particularly with respect to water vapour and ozone. Key improvements include larger data yields, reduced noise in the upper troposphere and smaller fluctuations in the bias profile at pressures larger than $100 \mathrm{hPa}$. The situation for temperature is less clear, with cold biases and noise levels in the upper troposphere, both larger in v4 than in v3. Several aspects of our results differ from those of validations conducted in other locations. These differences are often amplified by monsoon onset, indicating that the Asian monsoon anticyclone poses unique challenges for remote sensing that impact the quality of MLS retrievals in this region.

\section{Introduction}

Variations in temperature, water vapour and ozone in the upper troposphere and lower-middle stratosphere (UTLS) play critical roles in the Earth's radiation budget (Manabe and Wetherald, 1967) with important implications for climate 
change (Soden et al., 2008; Solomon et al., 2010; Dessler et al., 2013). Accurate observations of these variables at UTLS altitudes are difficult to obtain. Instruments mounted on balloonsondes and aircraft can be used to collect measurements with high resolution along specific flight tracks, but suffer from limited spatial and temporal coverage. Reanalyses and other data assimilation systems provide global coverage at frequent intervals, but are heavily influenced by the underlying numerical model and often do not assimilate observations of ozone or stratospheric water vapour. Satellite observations occupy something of a middle ground between them, with improved spatial and temporal coverage relative to sonde and aircraft measurements (at the expense of spatiotemporal resolution) and improved fidelity to the state of the atmosphere relative to reanalyses (at the expense of simultaneous global coverage).

Satellite retrievals are based on the mathematical processing and physical interpretation of observed atmospheric radiances, with errors and uncertainties that reflect imperfections in the design of the instrument used to conduct the observations and the algorithm used to process the observations. These errors can be globally systematic or vary with season and region, so that the evaluation and validation of satellite retrievals requires a geographically and temporally diverse set of independent validation measurements from a variety of observational and semi-observational platforms.

The Microwave Limb Sounder (MLS) instrument on board the Aura satellite has provided near-continuous sunsynchronous observations of temperature, water vapour and ozone in the upper troposphere, stratosphere and lower mesosphere since August 2004 (Waters et al., 2006). Four versions of MLS data have been released to the public to date. The initial production version, version 1.5 (v1.5), was replaced by version 2.2/2.3 (v2) in 2007 and version 3.3/3.4 (v3) in 2010. The most recent production version, version $4.2(\mathrm{v} 4)$, replaced v3 in February 2015.

The boreal summertime UTLS over the Tibetan Plateau is dominated by the Asian monsoon anticyclone. The composition and thermodynamic structure of this region differ substantially from other regions at this latitude and represent a mix of tropical and midlatitude characteristics (Park et al., 2007). The Tibetan Plateau region has been variously described as "the world's water tower" (Xu et al., 2008) and an "ozone valley" (Zhou et al., 1995; Tobo et al., 2008), and the Asian monsoon anticyclone has been identified as a key pathway for the transport of water vapour and pollutants across the tropopause and into the global stratosphere (Fu et al., 2006; Randel et al., 2010; Wright et al., 2011; Ploeger et al., 2013). Biases in Aura MLS are well characterized globally, with multiple validation analyses of temperature (Froidevaux et al., 2006; Schwartz et al., 2008), water vapour (Read et al., 2007; Lambert et al., 2007; Vömel et al., 2007a; Berthet et al., 2013; Hegglin et al., 2013; Hurst et al., 2014) and ozone (Jiang et al., 2007; Livesey et al., 2008; Tegtmeier et al., 2013) against radiosonde and ozonesonde

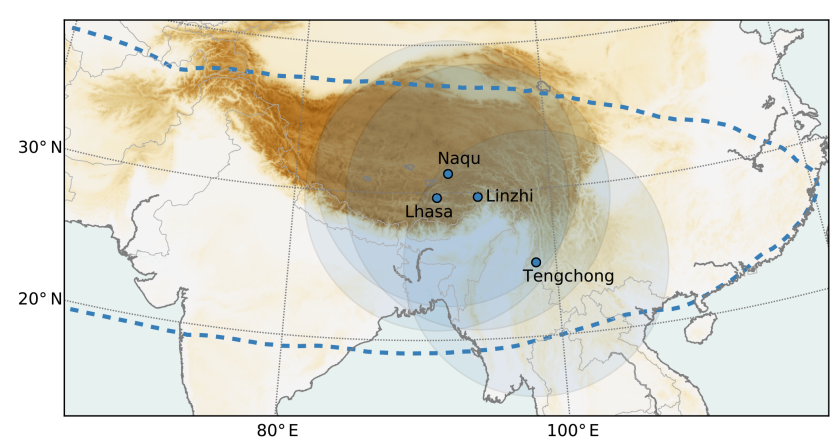

Figure 1. Locations of the radiosonde launch sites. The circular shaded areas cover a $1000 \mathrm{~km}$ radius from each site. The dashed contour corresponds to the $16770 \mathrm{gpm}$ contour of $100 \mathrm{hPa}$ geopotential height from the ERA-Interim reanalysis, averaged over July and August 1979-2014. The shading indicates topography, with darker colours corresponding to higher surface altitudes.

networks, frost point hygrometers, ground-based lidars, aircraft data and other satellite retrievals. However, despite extensive use and analysis of MLS retrievals in the vicinity of the Asian monsoon anticyclone (e.g. Park et al., 2007; Uma et al., 2014), few previous studies have conducted focused validations of MLS observations in this region (with the notable exception of Yan et al., 2015, which is discussed further below). Moreover, few of the field observations used to evaluate MLS retrievals in global validation studies have been collected in the vicinity of the Asian monsoon anticyclone. Characterization of biases in this region therefore relies on global and zonal mean comparisons with other satellite data sets.

Here, we present a validation of the third (v3) and fourth (v4) public releases of Aura MLS retrievals over the southeastern Tibetan Plateau and adjacent regions during boreal summer using balloon soundings collected at four sites over 4 different years (Fig. 1 and Table 1) during the Study of Ozone, Aerosols and Radiation over the Tibetan Plateau (SOAR-TP). The results provide a detailed evaluation of MLS retrievals of temperature, water vapour and ozone in the vicinity of the Asian monsoon anticyclone. We describe the in situ data, key differences between v3 and v4 and the validation methodology in Sect. 2 . We then present the results of the validation in Sect. 3 and discuss these results in the context of previous validation studies, related variables and differences between v3 and v4 in Sect. 4. We conclude with a summary of key findings in Sect. 5 .

\section{Data and methodology}

\subsection{Sonde measurements}

The balloon-borne sonde measurements used in this analysis were collected at four high-altitude locations in southwestern China (Fig. 1): Tengchong, Yunnan (August 2010); 
Table 1. Radiosonde site information for data used in this validation. The rightmost column lists the number of profiles for which a collocated Aura MLS profile was identified (see Sect. 2.3).

\begin{tabular}{lrrrrrr}
\hline Site & Geolocation & Altitude & Period & \multicolumn{2}{c}{ Number of profiles } \\
\cline { 4 - 6 } & & & & $T^{\mathrm{a}}$ & $\mathrm{H}_{2} \mathrm{O}$ & $\mathrm{O}_{3}{ }^{\mathrm{b}}$ \\
\hline Tengchong, Yunnan & $25.00^{\circ} \mathrm{N}, 98.50^{\circ} \mathrm{E}$ & $1656 \mathrm{~m}$ & August 2010 & 10 & 10 & 10 \\
Naqu, Tibet & $31.29^{\circ} \mathrm{N}, 92.04^{\circ} \mathrm{E}$ & $4500 \mathrm{~m}$ & August 2011 & 13 & 2 & 4 \\
Lhasa, Tibet & $29.66^{\circ} \mathrm{N}, 91.14^{\circ} \mathrm{E}$ & $3650 \mathrm{~m}$ & May-July 2012 & 28 & 8 & 25 \\
Linzhi, Tibet & $29.67^{\circ} \mathrm{N}, 94.33^{\circ} \mathrm{E}$ & $2992 \mathrm{~m}$ & June-July 2014 & 31 & 10 & 30 \\
\hline
\end{tabular}

${ }^{\mathrm{a}}$ Listed quantities are temperature profiles collected using Vaisala RS80 and RS92 instruments. Eighteen temperature profiles were also collected using InterMet (IMet) instruments at Lhasa (7) and Linzhi (11). ${ }^{\mathrm{b}}$ Two $\mathrm{O}_{3}$ profiles collected at Tengchong (17 and 22 August 2010) could not be matched to v3 MLS ozone retrievals that meet the quality control and collocation criteria. Both profiles were successfully matched to v4 MLS retrievals and included in the validation of v4 ozone.

Naqu, Tibet (August 2011); Lhasa, Tibet (May-July 2012) and Linzhi, Tibet (June-July 2014). Table 1 lists geolocation information for each of these sites and the numbers of temperature, water vapour and ozone profiles from each site used in the validation analysis. Temperature measurements were collected using Vaisala RS80 (Tengchong and Naqu) and RS92 (Naqu, Lhasa and Linzhi) radiosondes. Profiles of water vapour mixing ratio were collected using cryogenic frost point hygrometer (CFH) instruments attached to RS80 (Tengchong and Naqu) and InterMet (Lhasa and Linzhi) radiosondes, as the RS92 radiosonde does not permit the attachment of a CFH. The InterMet radiosondes released at Lhasa and Linzhi were launched together with RS92 radiosondes and are therefore directly comparable. Ozone measurements were collected using electrochemical concentration cell (ECC) instruments. Profiles of temperature, water vapour and ozone were obtained up to the burst point of each balloon, which typically occurred at altitudes greater than $30 \mathrm{~km}$ and pressures as low as 5 to $10 \mathrm{hPa}$. Launch times varied, but were predominantly during the early afternoon local time at Tengchong, Naqu and Lhasa and were predominantly around midnight local time at Linzhi.

The CFH is a microprocessor and chilled mirror instrument capable of measuring a large range of water vapour concentrations from the surface to approximately $28 \mathrm{~km}$ altitude (Vömel et al., 2007b). Cryogenic fluid is used to maintain the mirror at the frost point temperature, which is then converted to water vapour mixing ratio using the approximation to the Clausius-Clapeyron relation proposed by Goff and Gratch (1946). The uncertainty in CFH measurements is less than $10 \%$ in the upper troposphere and stratosphere.

ECC ozonesondes observe ozone mixing ratios by measuring electrical currents produced by reactions of $\mathrm{O}_{3}$ and potassium iodide (KI) in separate cathode and anode chambers. These electrical currents are directly proportional to the amount of ozone in the air which is pumped into the instrument. The minimum detection limit is approximately $2 \mathrm{ppbv}$, considerably less than the typical background value for clean tropospheric air (30 ppbv). ECC measurements are typically accurate to within $10 \%$ in the troposphere and $5 \%$ in the stratosphere up to $10 \mathrm{hPa}$ (Smit et al., 2007).

During flight, the $\mathrm{CFH}$ and ECC data streams were transmitted to receiving equipment on the ground through interfaces for the RS80 (Tengchong and Naqu), InterMet (Lhasa and Linzhi) and RS92 (Naqu, Lhasa and Linzhi; ECC only) radiosondes. These data were stored together with profiles of pressure, temperature and other variables observed by the radiosonde instrument. The payloads weighed approximately $1 \mathrm{~kg}$ and were flown using $1600 \mathrm{~g}$ latex balloons filled with hydrogen. Although only ascending data are analysed here, each balloon was equipped with a parachute to enable the potential use of data collected during descent and recovery of the instrument package.

\subsection{Aura MLS temperature, water vapour and ozone retrievals}

Versions 3 and 4 of the MLS retrieval algorithm have been used to process the third and fourth public releases of MLS data respectively (henceforth referred to as $\mathrm{v} 3$ and $\mathrm{v} 4$ ). Both versions of the data consist of profiles reported on 12 pressure levels per decade between 1000 and $1 \mathrm{hPa}, 6$ pressure levels per decade between 1 and $0.1 \mathrm{hPa}$, and 3 pressure levels per decade between 0.1 and $0.01 \mathrm{hPa}$. The MLS measurement system uses optimal estimation theory (Rodgers, 2000 ) to retrieve an atmospheric state vector (Livesey et al., 2013, 2015). Temperature profiles are retrieved using radiances near the $\mathrm{O}_{2}$ spectral bands at $118 \mathrm{GHz}$ (for the stratosphere and above) and $239 \mathrm{GHz}$ (for the troposphere), water vapour profiles are retrieved using radiances at $190 \mathrm{GHz}$ and ozone profiles are retrieved using radiances at $240 \mathrm{GHz}$. The atmospheric state vector produced by the full retrieval algorithm contains estimates of temperature, water vapour and ozone at 55 pressure levels (as well as other variables that are not considered here). The profiles used in this validation analysis have been screened using the quality control criteria suggested by Livesey et al. (2013) for v3 and Livesey et al. (2015) for v4 (reproduced in Appendix A). We validate MLS profiles of water vapour, temperature and ozone 

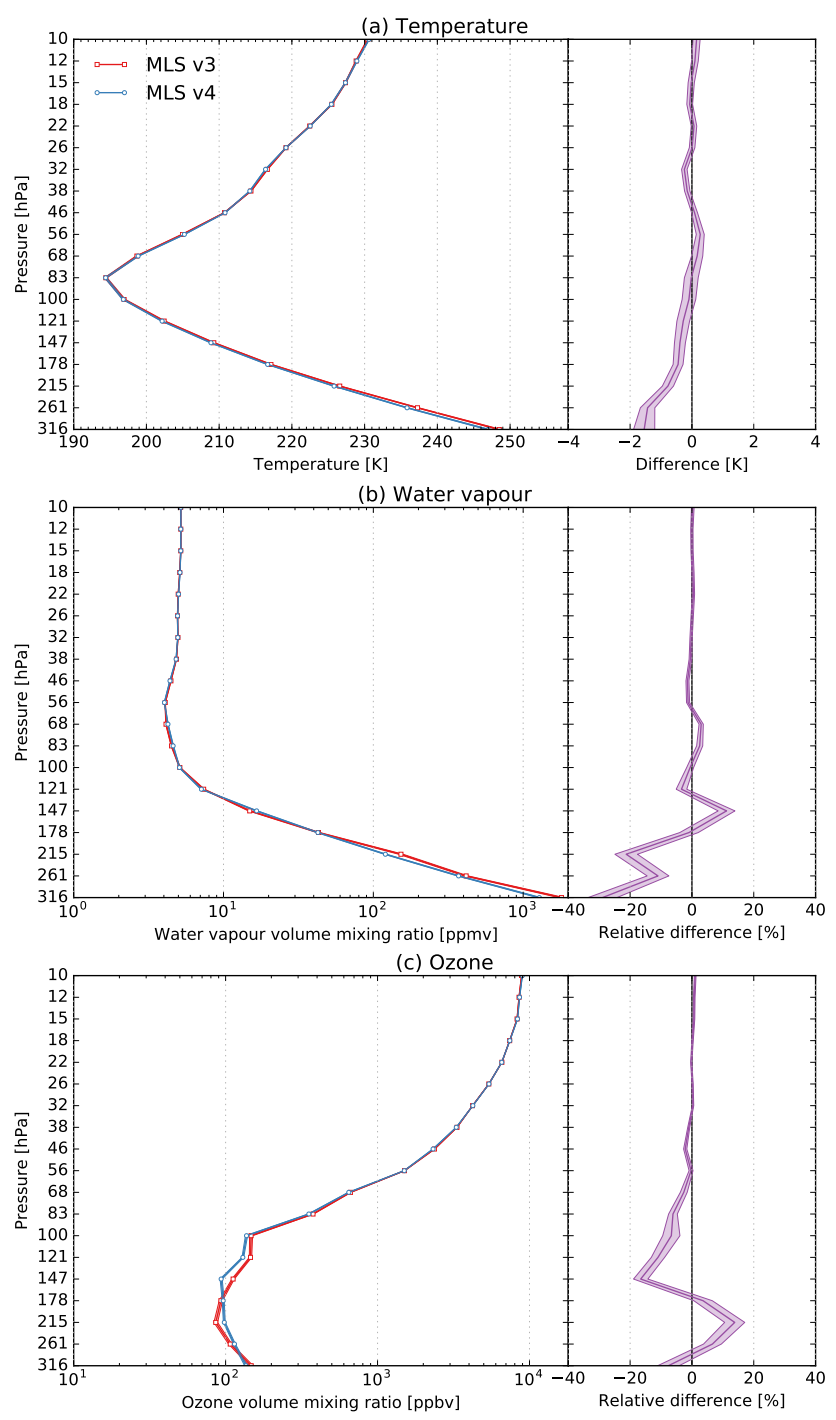

Figure 2. Mean profiles of (a) temperature, (b) water vapour volume mixing ratio and (c) ozone volume mixing ratio from MLS v3 and MLS v4 within one or more of the circular shaded areas outlined in Fig. 1 during the months corresponding to the four measurement campaigns (August 2010, August 2011, May-July 2012 and June-July 2014). Differences (v4 minus v3) are shown on the right. Relative differences in water vapour and ozone are calculated relative to $\mathrm{v} 3$ mixing ratios. Uncertainty bounds represent combined measurement (estimated retrieval precision) and statistical (twice the standard error of the mean) uncertainties.

at the 19 standard MLS pressure levels between 316 and $10 \mathrm{hPa}$ (see Fig. 2). Although MLS retrievals of temperature and ozone at pressures greater than $261 \mathrm{hPa}$ are currently not recommended for use in scientific studies, we evaluate and briefly discuss the performance of retrievals of both variables at $316 \mathrm{hPa}$.

Uncertainties in MLS measurements are estimated by combining the precisions of the radiance observations with uncertainties in the a priori estimates as described by
Rodgers (1976). These uncertainty estimates represent the diagonal elements of the solution covariance matrix and are provided for each profile in the MLS Level 2 data files. Positive values of precision in MLS products indicate that retrievals depend mainly on observed radiances rather than a priori estimates (precisions are explicitly set to negative by the software to flag retrievals that are significantly affected by their a priori estimates). The root mean square (rms) precision of individual MLS temperature profiles over this region (see domain outlined in Fig. 1) during the four measurement campaigns was $0.5-1.3 \mathrm{~K}$ in $\mathrm{v} 3$ and $0.5-1.0 \mathrm{~K}$ in $\mathrm{v} 4$ for the 19 pressure levels included in this validation. The corresponding rms precision of individual water vapour volume mixing ratio profiles was $4-39 \%$ in v3 and 4-8\% in v4, and the rms precision of individual ozone volume mixing ratio profiles between 10 and $261 \mathrm{hPa}$ was $1-124 \%$ in v3 $(100 \%$ at $316 \mathrm{hPa})$ and $1-28 \%$ in $\mathrm{v} 4(490 \%$ at $316 \mathrm{hPa})$. In most cases, MLS precisions at a given level are fairly constant in mixing ratio space. Fractional precisions will therefore vary substantially for species with large fluctuations in the horizontal or time dimensions (including water vapour and ozone in the upper troposphere).

Figure 2 shows mean profiles of temperature, water vapour and ozone from $\mathrm{v} 3$ and $\mathrm{v} 4$ within $1000 \mathrm{~km}$ of one or more of the launch sites (circular shaded areas in Fig. 1). Differences in mean profiles of temperature, water vapour and ozone based on these two versions of MLS data are small, particularly at stratospheric pressure levels $(10-68 \mathrm{hPa})$. Mean temperatures in the upper troposphere $(121-261 \mathrm{hPa})$ are colder in $\mathrm{v} 4$ than in $\mathrm{v} 3$ by $0.28-1.43 \mathrm{~K}$ (all differences are significant when both measurement and statistical uncertainty are accounted for). The mean $\mathrm{v} 4$ temperature profile is also colder than $\mathrm{v} 3$ at $31-38 \mathrm{hPa}$ (by approximately $0.2 \mathrm{~K}$ ) and warmer than $\mathrm{v} 3$ at $56 \mathrm{hPa}(0.27 \pm 0.13 \mathrm{~K})$ and $10 \mathrm{hPa}$ $(0.15 \pm 0.11 \mathrm{~K})$. Mean water vapour mixing ratios in the upper troposphere $(215-316 \mathrm{hPa})$ are smaller in $\mathrm{v} 4$ than in v3 (with a maximum relative bias of $-29 \pm 5 \%$ at $316 \mathrm{hPa}$ ), but slightly larger in $\mathrm{v} 4$ than in $\mathrm{v} 3$ at $147 \mathrm{hPa}(11 \pm 3 \%)$. Differences in the remainder of the profile are within $\pm 3 \%$. The most significant change in ozone is a reduction in vertical gradients in the upper troposphere and lower tropopause layer $(100-316 \mathrm{hPa})$ in $\mathrm{v} 4$ relative to $\mathrm{v} 3$. This vertical homogenization results in better qualitative agreement with the vertical structure of mean ozonesonde profiles from independent observations over Lhasa and Kunming during boreal summer (Bian et al., 2012) and includes statistically significant decreases of $6-17 \%$ in mean ozone mixing ratios in the tropopause layer $(83-147 \mathrm{hPa})$ and statistically significant increases of 4-14\% in the upper troposphere $(178-261 \mathrm{hPa})$.

The mean profiles shown in Fig. 2 are based on slightly different samples due to differences in the retrieval algorithm and quality control criteria. Specifically, v4 provides increased data yields in this region relative to v3 $(10 \%$ more temperature profiles, $32 \%$ more water vapour profiles and $29 \%$ more ozone profiles). These increased data yields pri- 
marily reflect changes in the MLS quality screening criteria, which have been updated to account for changes in the way that clouds are handled during the retrieval step. One of the primary goals of MLS $v 4$ was to improve the behaviour of MLS upper tropospheric composition retrievals in the presence of clouds. This was accomplished by redefining the manner in which clouds were represented in the MLS forward model and redesigning the method by which the strongest cloud signals in the MLS radiances are flagged and excluded from the retrievals. These changes significantly reduce the sensitivity of the MLS composition observations to cloud scattering signals. Relative differences between $\mathrm{v} 3$ and $\mathrm{v} 4$ are effectively unchanged when the comparison is limited to retrievals that meet quality control criteria in both $\mathrm{v} 3$ and v4.

\subsection{Validation methodology}

Differences between sonde measurements and MLS retrievals can arise from several factors, including differences in vertical resolution or interpolation techniques, measurement errors in the sonde and MLS profiles, spatio-temporal inhomogeneities due to synoptic variability and smoothing associated with the horizontal extent of the MLS footprint. The estimated response time of the CFH and ECC instruments are both of the order of $10 \mathrm{~s}$ to $1 \mathrm{~min}$. At typical ascent rates of 5-7 $\mathrm{m} \mathrm{s}^{-1}$, this corresponds to a vertical resolution of 50-400 m. By contrast, the vertical resolution of MLS profiles is of the order of a few kilometres $(3.6-5.0 \mathrm{~km}$ for temperature, $2.0-3.7 \mathrm{~km}$ for water vapour and $\sim 2.5 \mathrm{~km}$ for ozone). The radiosonde profiles must therefore be resampled to match the lower vertical resolution of the MLS profiles. Here, we resample the radiosonde profiles of temperature, water vapour and ozone by applying the MLS forward model smoothing operator and appropriate averaging kernels (Read et al., 2006; Livesey et al., 2013, 2015). This approach to resampling the sonde profiles at MLS resolution differs notably from the linear interpolation method used by Yan et al. (2015).

First, the resolution of the observed in situ profile is degraded to the resolution of the MLS product using the equation

$\bar{X}_{\mathrm{s}}=X_{\mathrm{s}} \eta^{\mathrm{T}}\left(\eta \eta^{\mathrm{T}}\right)^{-1}$,

where $X_{\mathrm{s}}$ is the sonde profile at its original resolution, $\eta^{\mathrm{T}}\left(\eta \eta^{\mathrm{T}}\right)^{-1}$ is the forward model smoothing operator (with $\eta$ dependent on the sonde and MLS pressure profiles as described by Read et al., 2006) and $\bar{X}_{\mathrm{s}}$ is the sonde profile sampled at MLS resolution. The reduced-resolution sonde profile is then convolved with the averaging kernel using the equation

$\hat{X}_{\mathrm{s}}=X_{\mathrm{ap}}+\left[\bar{X}_{\mathrm{s}}-X_{\mathrm{ap}}\right] \mathbf{A}$, where $X_{\text {ap }}$ is the a priori profile for collocated retrieval and A is the averaging kernel. The resulting profile $\hat{X}_{\mathrm{s}}$ is appropriate for direct comparison with the collocated MLS profile. Forward smoothing and convolution of water vapour profiles are done using the logarithm of water vapour volume mixing ratio as recommended by Read et al. (2007), while forward smoothing and convolution of temperature and ozone profiles are done using temperature and ozone volume mixing ratio directly (see also Livesey et al., 2015, and references therein). MLS averaging kernels differ by variable and data version. Sonde profiles are convolved with $\mathrm{v} 3$ averaging kernels for validating $\mathrm{v} 3$ retrievals and with $\mathrm{v} 4$ averaging kernels for validating $\mathrm{v} 4$ retrievals. The comparisons presented below use the standard publicly released averaging kernels, which are derived for the equator. The results are effectively unchanged when these are replaced with averaging kernels derived specifically for the Asian monsoon region.

Appropriate collocation criteria for MLS validation may vary by region, season or variable of interest and should be evaluated independently for each validation campaign. Vömel et al. (2007a) used CFH measurements to validate Aura MLS version 1 and 2 observations of water vapour and found that their results were largely insensitive to the choice of distance thresholds up to $900 \mathrm{~km}$ and time difference thresholds up to $12 \mathrm{~h}$. We begin by choosing the geographically closest MLS retrievals of temperature, water vapour and ozone within $\pm 6 \mathrm{~h}$ of balloon launch that satisfy the quality control criteria outlined in Sect. 2.2. If any of these retrievals are within $1000 \mathrm{~km}$ of the launch site, then we choose the geographically closest retrieval for comparison. If not, then we extend the time window to $\pm 12 \mathrm{~h}$ and repeat the process This two-step selection process allows us to preferentially select retrievals from orbits that are close in time to the in situ measurements, limiting spurious effects caused by sampling different parts of the diurnal cycle (although sensitivity analysis indicates that these effects are small) while maximizing the validation sample size. Our conclusions are qualitatively robust to reasonable changes in these criteria: sensitivity to choices of smaller distance or time thresholds is mainly limited to data yields, with no major changes in bias statistics. Application of the combined collocation and quality control criteria eliminates only two ozone profiles from the analysis, and those two profiles are eliminated only from the v3 validation (both profiles are successfully matched to valid v4 ozone retrievals). The vast majority of profiles are matched within $\pm 6 \mathrm{~h}$ (76-85\%, depending on the variable and data version), with a mean time difference for all matched profiles of approximately $3.5 \mathrm{~h}$. Distances between the launch site and the nominal centre of the matched MLS footprint range from 37 to $983 \mathrm{~km}$, with a mean of approximately $500 \mathrm{~km}$

We report temperature biases as absolute differences in Kelvins; however, we report biases in water vapour and ozone mixing ratios as relative differences. The use of relative differences for water vapour and ozone accounts for vari- 


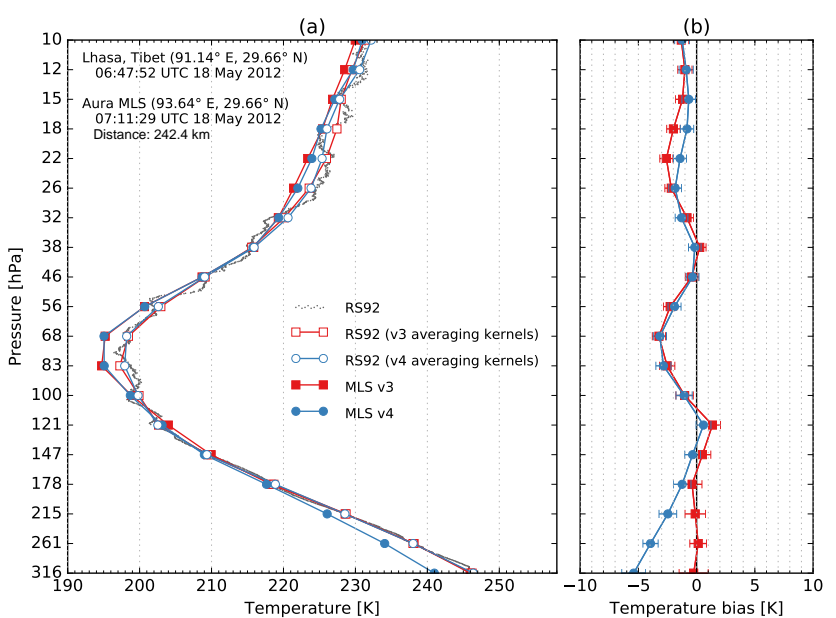

Figure 3. (a) RS92 and MLS v3 and v4 temperature profiles measured at Lhasa, Tibet on 18 May 2012. The satellite overpass was offset from the launch site by $242 \mathrm{~km}$ ( $0^{\circ}$ latitude, $2.5^{\circ}$ longitude). The balloon was launched $24 \mathrm{~min}$ prior to the overpass and reached $191 \mathrm{hPa}$ at the time of the overpass. (b) Absolute biases (in K) between the MLS v3/v4 profiles and the sonde profile interpolated to MLS pressure levels using the v3/v4 MLS forward functions and averaging kernels. Error bars represent the MLS measurement uncertainty.

ations of 2-3 orders of magnitude in typical concentrations of these species within the upper troposphere and lower-middle stratosphere and facilitates comparison with previous validation studies. We include a brief summary of absolute ozone biases for context, as many of the sources of error for MLS ozone retrievals act on absolute mixing ratios rather than relative mixing ratios.

Relative differences are defined with respect to the sonde measurement and are calculated using the equation

$\delta(p)=\frac{X_{\mathrm{M}}(p)-\hat{X}_{\mathrm{S}}(p)}{\hat{X}_{\mathrm{S}}(p)}$,

where $X_{\mathrm{M}}(p)$ is the MLS retrieval at a given pressure level and $\hat{X}_{\mathrm{S}}(p)$ is the sonde measurement convolved to that level using Eqs. (1)-(2). We report three bias statistics at each level for each variable: the arithmetic mean bias, the median bias and the root mean square (rms) bias. The range of biases at each level is indicated by twice the standard error of the mean bias (an approximate $95 \%$ confidence interval around the mean) and the interquartile range (which spans the middle $50 \%$ of biases at each level). For water vapour and ozone, non-robust statistical measures (mean, standard error and rms) are calculated using absolute differences and then normalized by the mean of the convolved sonde observations at each level.

\section{Results}

\subsection{Temperature}

Figure 3 shows temperature profiles and biases based on RS92 radiosonde measurements and MLS v3 and v4 retrievals collected near Lhasa on 18 May 2012. The balloon was launched $24 \mathrm{~min}$ prior to the MLS retrieval and had reached $191 \mathrm{hPa}$ at the time of the MLS overpass. The centre of the MLS footprint was located $242 \mathrm{~km}$ due east of the radiosonde launch site. Application of the forward smoothing function and the v3 or v4 averaging kernel eliminates much of the fine structure in the radiosonde profile, but the resulting low-resolution profiles are consistent with the vertical structure of the in situ measurements at kilometre scales. Both v3 and v4 MLS retrievals are colder than the RS92 measurements in the middle stratosphere $(10-32 \mathrm{hPa})$ and in the lower stratosphere and tropopause layer $(56-100 \mathrm{hPa})$, while the v4 retrieval is substantially colder than both RS92 measurements and the MLS v3 retrieval in the upper troposphere $(215-316 \mathrm{hPa})$. Differences between $\mathrm{v} 3$ biases and $\mathrm{v} 4$ biases are due in part to differences in the MLS retrievals and in part to differences in the RS92 profile convolved to MLS pressure levels. Both of these factors potentially reflect changes in the averaging kernel and the a priori profile (see Sect. 2.3), while the former also reflects changes in how the retrieval algorithm processes the observed radiances. The following discussion is based on a statistical analysis of 82 profiles, including the profile shown in Fig. 3.

Figure 4 shows mean, median and rms biases for MLS v3 and $\mathrm{v} 4$ temperature retrievals relative to RS80/RS92 temperature measurements. Bias statistics at each level are based on the subset of radiosondes that reach that level, with sample sizes that range from 43 measurements at $10 \mathrm{hPa}$ to 82 measurements at $316 \mathrm{hPa}$. Mean and median temperature biases agree well at most levels, although cold biases near the tropopause $(68-83 \mathrm{hPa})$ are slightly larger in the median than in the mean. Both v3 and v4 agree well with the sonde profiles in the same portions of the profile, with layers of near-zero mean biases at 18,46 and $100-121 \mathrm{hPa}$ alternating with layers of cold biases centred at $10-12 \mathrm{hPa}(-1.5 \pm 0.5 \mathrm{~K}$ in v3; $-1.3 \pm 0.5 \mathrm{~K}$ in v4), $26-32 \mathrm{hPa}(-1.5 \pm 0.3 \mathrm{~K}$ in v3; $-1.7 \pm 0.3 \mathrm{~K}$ in $\mathrm{v} 4), 68-83 \mathrm{hPa}(-1.8 \pm 0.4 \mathrm{~K}$ in both $\mathrm{v} 3$ and v4) and $147-261 \mathrm{hPa}(-2.3 \pm 0.3 \mathrm{~K}$ in v3; $-2.6 \pm 0.4 \mathrm{~K}$ in $\mathrm{v} 4)$. Vertical oscillations in the bias profile are a well-known feature of previous versions of MLS temperature retrievals (Schwartz et al., 2008), although their underlying causes are still not well understood (Livesey et al., 2013).

Figure 5 and the upper rows of Table 2 summarize the validation statistics for temperature retrievals in three layers of the atmosphere chosen to represent the stratosphere $(10-56 \mathrm{hPa})$, tropopause layer $(68-147 \mathrm{hPa})$ and upper troposphere $(178-261 \mathrm{hPa})$. Observations at $316 \mathrm{hPa}$ are omitted from the upper troposphere layer average, as temperature retrievals at this layer are not recommended for scientific use in 

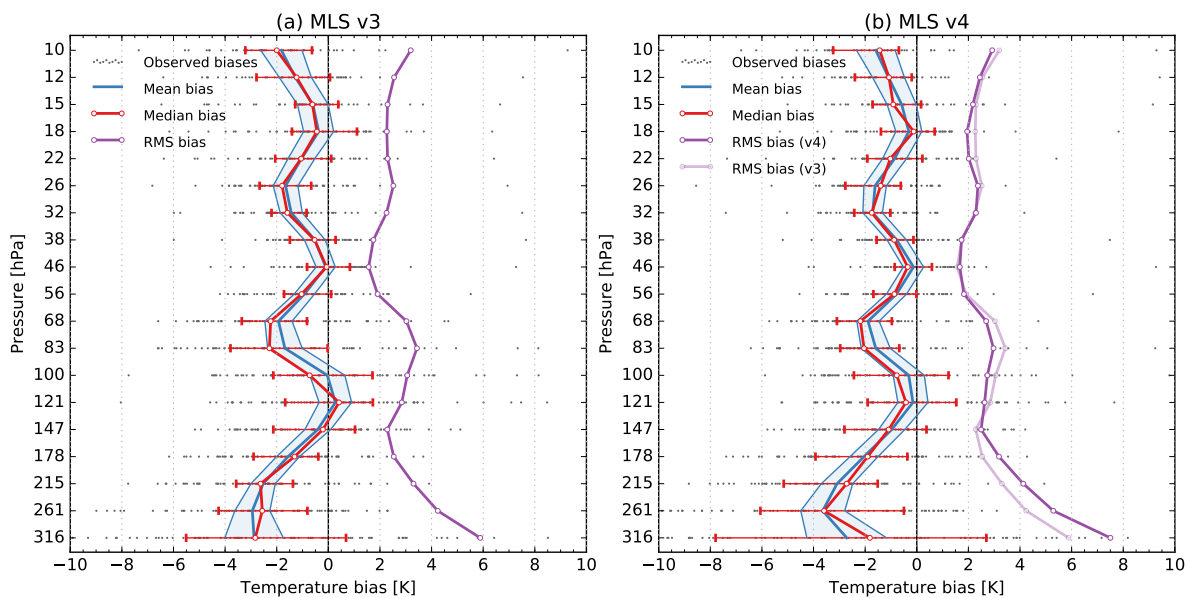

Figure 4. Mean, median and root mean square biases for (a) MLS v3 and (b) MLS v4 temperature profiles relative to RS80 and RS92 temperature profiles interpolated to MLS pressure levels using the respective MLS forward function and averaging kernel. Uncertainty bounds on the mean bias (blue shaded envelope bounded by thin blue lines) represent twice the standard error of the mean, while error bars on the median bias (red error bars) indicate the interquartile range (IQR). Results for individual profiles are shown as grey points.

Table 2. Statistical summary of the validation results for MLS v3 (left) and v4 (right) for three atmospheric layers. Layer averages are pressure weighted. The biases of the rms are calculated as the rms MLS value minus the rms sonde value (normalized by the rms sonde value for water vapour and ozone). Correlations are Pearson's $r$, tested at the $95 \%$ confidence level using Student's $t$ test.

\begin{tabular}{|c|c|c|c|c|c|c|c|c|c|}
\hline & \multirow[b]{2}{*}{ Layer } & \multicolumn{4}{|c|}{ MLS v3 } & \multicolumn{4}{|c|}{ MLS v4 } \\
\hline & & Mean bias & rms bias & Biases of rms & Correlation & Mean bias & rms bias & Biases of rms & Correlation \\
\hline \multirow{3}{*}{ 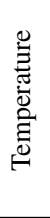 } & $\begin{array}{l}\text { Stratosphere } \\
(10-56 \mathrm{hPa})\end{array}$ & $-0.9 \pm 0.2$ & $1.6 \mathrm{~K}$ & $-0.9 \mathrm{~K}$ & 0.89 & $-0.9 \pm 0.2$ & $1.6 \mathrm{~K}$ & $-0.9 \mathrm{~K}$ & 0.90 \\
\hline & $\begin{array}{l}\text { Tropopause layer } \\
(68-147 \mathrm{hPa})\end{array}$ & $-0.6 \pm 0.3$ & $2.4 \mathrm{~K}$ & $-0.6 \mathrm{~K}$ & 0.52 & $-0.9 \pm 0.2$ & $2.2 \mathrm{~K}$ & $-0.9 \mathrm{~K}$ & 0.51 \\
\hline & $\begin{array}{l}\text { Upper troposphere } \\
(178-261 \mathrm{hPa})\end{array}$ & $-2.4 \pm 0.3$ & $3.1 \mathrm{~K}$ & $-2.4 \mathrm{~K}$ & 0.37 & $-3.0 \pm 0.4$ & $3.8 \mathrm{~K}$ & $-3.0 \mathrm{~K}$ & 0.36 \\
\hline \multirow{3}{*}{ 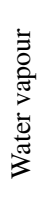 } & $\begin{array}{l}\text { Stratosphere } \\
(10-56 \mathrm{hPa})\end{array}$ & $-\mathbf{3} \pm \mathbf{2} \%$ & $8 \%$ & $-1 \%$ & 0.54 & $-2 \pm 2 \%$ & $9 \%$ & $-1 \%$ & 0.45 \\
\hline & $\begin{array}{l}\text { Tropopause layer } \\
(68-147 \mathrm{hPa})\end{array}$ & $-\mathbf{9} \pm \mathbf{5} \%$ & $37 \%$ & $-22 \%$ & 0.63 & $-11 \pm 6 \%$ & $41 \%$ & $-22 \%$ & 0.58 \\
\hline & $\begin{array}{l}\text { Upper troposphere } \\
(178-316 \mathrm{hPa})\end{array}$ & $-13 \pm 18 \%$ & $104 \%$ & $+18 \%$ & 0.26 & $-23 \pm 12 \%$ & $63 \%$ & $-12 \%$ & 0.46 \\
\hline \multirow{3}{*}{ 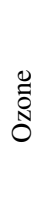 } & $\begin{array}{l}\text { Stratosphere } \\
(10-56 \mathrm{hPa})\end{array}$ & $+\mathbf{1 3} \pm \mathbf{1} \%$ & $11 \%$ & $+10 \%$ & 0.98 & $+\mathbf{1 3} \pm \mathbf{1} \%$ & $11 \%$ & $+10 \%$ & 0.98 \\
\hline & $\begin{array}{l}\text { Tropopause layer } \\
(68-147 \mathrm{hPa})\end{array}$ & $+\mathbf{2 7} \pm \mathbf{5} \%$ & $39 \%$ & $+34 \%$ & 0.54 & $+12 \pm 4 \%$ & $25 \%$ & $+20 \%$ & 0.69 \\
\hline & $\begin{array}{l}\text { Upper troposphere } \\
(178-261 \mathrm{hPa})\end{array}$ & $-11 \pm 15 \%$ & $97 \%$ & $+77 \%$ & 0.26 & $+\mathbf{1 2} \pm \mathbf{9} \%$ & $52 \%$ & $+27 \%$ & 0.37 \\
\hline
\end{tabular}

either v3 or v4. Pressure-weighted mean and rms temperature biases in the stratospheric layer are effectively unchanged between v3 and v4. The magnitude of the pressure-weighted mean temperature bias in the tropopause layer has increased slightly from v3 to $\mathrm{v} 4$, despite a slight reduction in the rms bias in this layer. The magnitude of the pressure-weighted mean temperature bias in the upper troposphere has also increased slightly; however, unlike the tropopause layer, this increase in mean bias is not balanced by a decrease in the rms bias, which is $0.7 \mathrm{~K}$ larger in $\mathrm{v} 4$ than in v3. This increase in rms biases (and the similar increase in IQR) indicates increased noise in upper tropospheric temperature retrievals in $\mathrm{v} 4$ relative to $\mathrm{v} 3$. Biases between the rms MLS and sonde temperatures are the same as the mean biases for all three layers, within uncertainties.

In addition to RS80 and RS92 radiosondes, 18 InterMet (IMet) radiosondes were launched at Lhasa (7) and Linzhi (11). All but one of the IMet radiosondes were launched together with an RS92 radiosonde, allowing for a comparative evaluation of MLS temperature biases relative to the two sets 


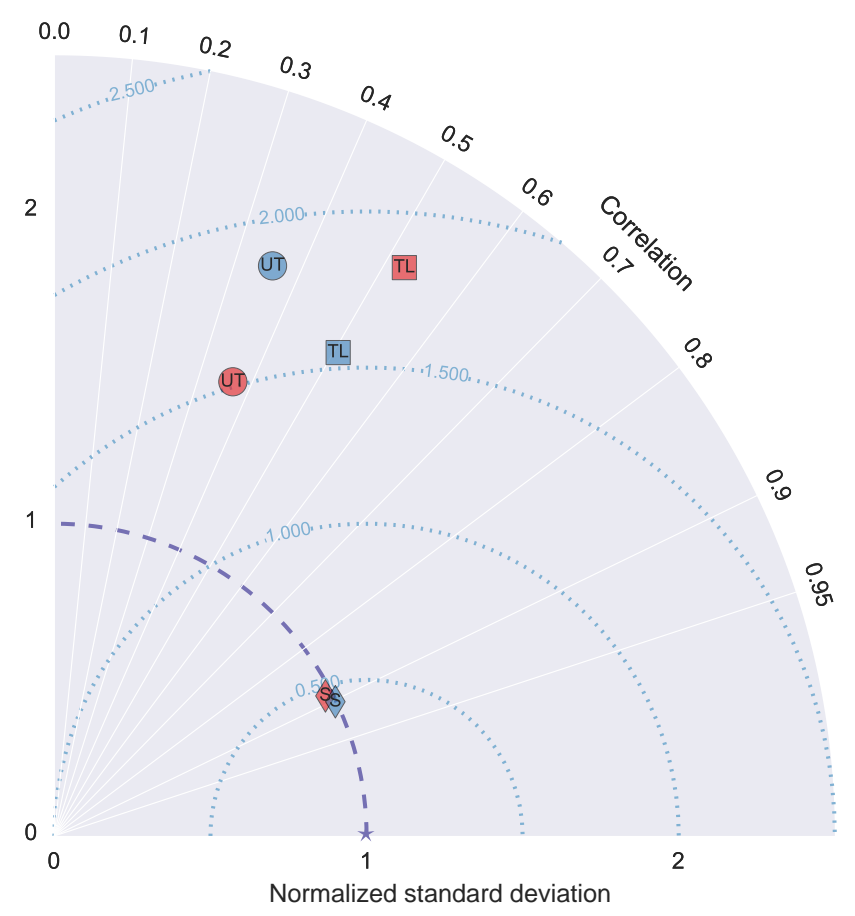

Figure 5. Modified Taylor diagram summarizing the performance of MLS v3 (red) and v4 (blue) retrievals relative to sonde measurements in three atmospheric layers: the upper troposphere (UT; circles; 178-261 hPa), tropopause layer (TL; squares; $68-147 \mathrm{hPa}$ ) and the stratosphere (S; diamonds; $10-56 \mathrm{hPa}$ ). Layer averages are pressure weighted, as in the text. Blue dotted lines mark isolines of root mean square error (RMSE) relative to the corresponding sonde measurements (purple star).

of radiosonde profiles. Figure 6 shows mean and rms temperature biases relative to collocated IMet and RS92 radiosondes, with sample sizes ranging from 10 samples (10-12 hPa) to 17 samples (32-316 hPa). The two bias estimates are qualitatively identical; the only notable difference is that the magnitudes of mean and rms biases relative to IMet are slightly larger than the magnitudes of mean and rms biases relative to RS92 in the tropopause layer $(68-100 \mathrm{hPa})$ for both $\mathrm{v} 3$ and $\mathrm{v} 4$ (note that this difference is consistent with the $\sim 0.5 \mathrm{~K}$ magnitude of previously reported biases between IMet and RS92 temperature measurements over California, but is opposite in sign and less persistent in altitude; Hurst et al., 2011). The overall agreement between bias estimates relative to IMet and bias estimates relative to RS92 indicates that the temperature validation presented here is robust to the choice of radiosonde instrumentation.

\subsection{Water vapour}

Figure 7 shows profiles of water vapour volume mixing ratio from 18 May 2012 based on CFH measurements and MLS v3 and v4 retrievals collected near Lhasa on 18 May 2012. These water vapour profiles correspond to the temper- ature profiles shown in Fig. 3. Application of the forward smoothing function and averaging kernel again eliminate the fine-scale structure in the CFH profile. The resulting lowresolution profiles are consistent with the kilometre-scale vertical structure of the CFH profile in the stratosphere (18$83 \mathrm{hPa}$ ), but are unable to accurately capture several deep layers of relatively dry and moist air below the tropopause (100-261 hPa). Biases in MLS v3 and v4 are small (within approximately $\pm 20 \%$ ) between 18 and $100 \mathrm{hPa}$. The large moist bias (70-80\%) centred at $147 \mathrm{hPa}$ may reflect weatherrelated horizontal gradients in water vapour in the upper troposphere and tropopause layer, which may be associated with horizontal variations in convective activity (current or previous) or radiatively driven ascent. This spatial variability should average out at larger sample sizes, but its impact will still be reflected in the spread around the mean and median biases at these levels. We discuss this topic in more detail in Sect. 4. The large dry biases at 261 and $316 \mathrm{hPa}$ reflect the impact of a sharp increase in the CFH water vapour measurements at approximately $320 \mathrm{hPa}$ (not shown) on the values convolved to these two levels using Eqs. (1) and (2).

Figure 8 shows mean, median and rms biases for MLS v3 and $\mathrm{v} 4$ retrievals of water vapour volume mixing ratio relative to $\mathrm{CFH}$ measurements. The number of samples used to calculate these statistics varies from two samples at $18 \mathrm{hPa}$ to 30 samples at $121-316 \mathrm{hPa}$. The number of samples is 10 or larger from 32 to $316 \mathrm{hPa}$. Mean biases are within $\pm 20 \%$ at all levels above $100 \mathrm{hPa}$. A statistically significant dry bias is identified at $22-32 \mathrm{hPa}(-9 \pm 4 \%$ in v $3 ;-8 \pm 4 \%$ in v4) and a statistically significant moist bias is identified at $68-83 \mathrm{hPa}$ ( $6 \pm 4 \%$ in v3; $12 \pm 5 \%$ in v4). Mean biases between 121 and $261 \mathrm{hPa}$ are generally negative in both $\mathrm{v} 3$ and v4, with the exception of v3 at $215 \mathrm{hPa}$. Pressure-weighted mean biases in this layer are $-23 \pm 15 \%$ in v 3 and $-32 \pm 11 \%$ in $\mathrm{v} 4$. Mean biases at $316 \mathrm{hPa}$ are near zero in both v3 and v4. Biases of rms in water vapour volume mixing ratio through most of the UTLS are similar between v3 and v4. Biases of rms are low in the stratosphere, increase gradually through the tropopause layer, then increase sharply into the upper troposphere, particularly in v3. Substantial reductions in the rms bias, standard error and IQR at $316 \mathrm{hPa}$ in v4 relative to $\mathrm{v} 3 \mathrm{in}-$ dicate that retrieved values at this level are substantially less noisy in $\mathrm{v} 4$. By contrast, slight increases in rms bias through the tropopause layer and lower stratosphere $(56-147 \mathrm{hPa})$ suggest that increased data yields in $v 4$ (see Sect. 2.2) may slightly increase overall noise levels in this vertical range.

Figure 9 and the middle rows of Table 2 summarize the validation statistics for water vapour retrievals in three layers of the atmosphere chosen to represent the stratosphere $(10-56 \mathrm{hPa})$, tropopause layer $(68-147 \mathrm{hPa})$ and upper troposphere $(178-316 \mathrm{hPa})$. The pressure-weighted mean bias in the stratosphere is slightly reduced in v4 relative to v3, while the bias in the tropopause layer is slightly increased (although neither change is statistically significant). The dry bias in the upper troposphere is also slightly larger in $\mathrm{v} 4$ than 

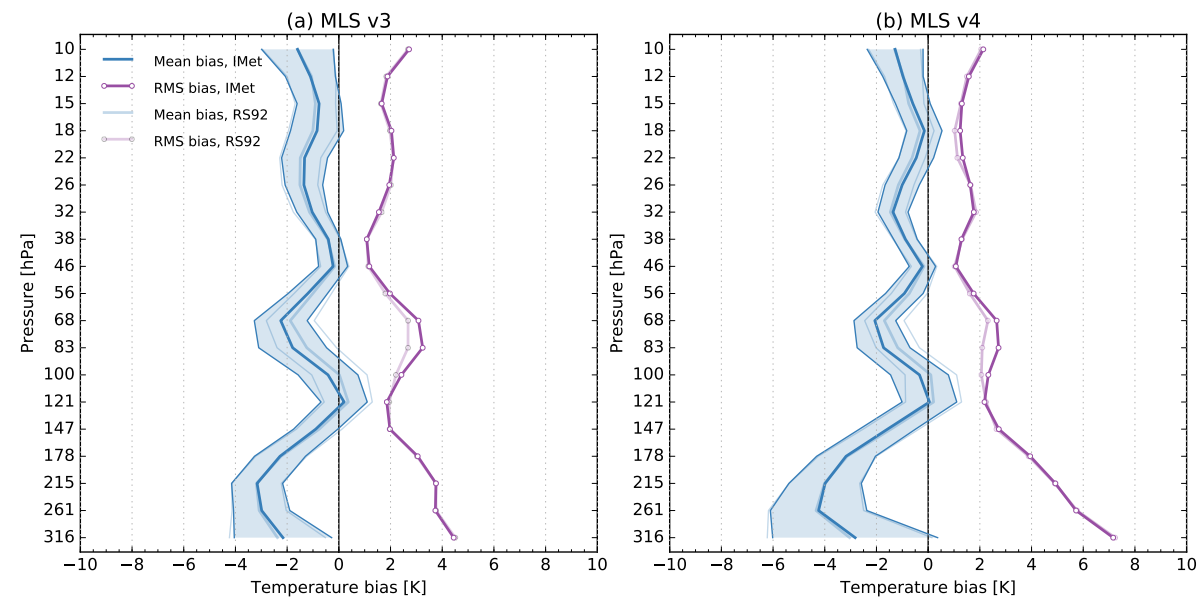

Figure 6. Mean and root mean square biases for (a) MLS v3 and (b) MLS v4 temperature retrievals relative to 17 temperature profiles at Lhasa and Linzhi measured using both InterMet (IMet) and RS92 radiosondes. Uncertainty bounds on the mean bias represent twice the standard error of the mean.

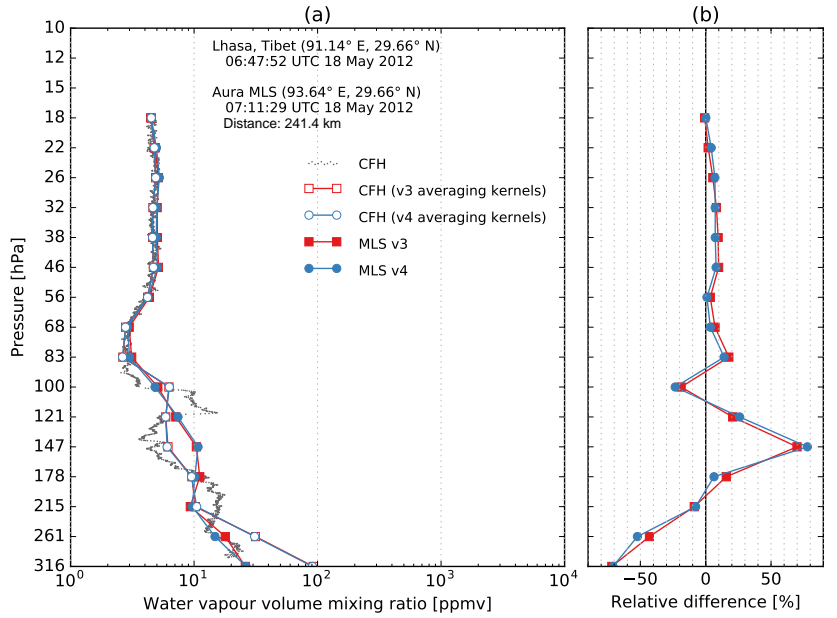

Figure 7. As in Fig. 3, but for CFH, MLS v3 and MLS v4 profiles of water vapour volume mixing ratio.

in $\mathrm{v} 3$, consistent with $\mathrm{v} 4$ retrievals in the upper troposphere for this region and season, being systematically drier than $\mathrm{v} 3$ retrievals (Fig. 2b). However, both the rms bias and the bias between the MLS and sonde rms values are substantially reduced in v4 relative to v3, further indicating that MLS retrievals of water vapour in the upper troposphere are much less noisy in v4 than in v3, despite the greater data yields in v4. Median biases in water vapour volume mixing ratio for v4 (Fig. 8b) are very close to the mean biases at pressures less than or equal to $100 \mathrm{hPa}$, but diverge slightly from the mean biases at several levels with pressures greater than $100 \mathrm{hPa}$, indicating that the mean bias may slightly overestimate the dry bias in this layer. Approximately $70 \%$ of the observed biases between 121 and $261 \mathrm{hPa}$ are negative for both $\mathrm{v} 3$ and $\mathrm{v} 4$, indicating that MLS water vapour retrievals in the up- per troposphere over the eastern Tibetan Plateau are typically drier than collocated CFH measurements in both versions.

\subsection{Ozone}

Figure 10 shows profiles of ozone from ECC measurements and v3 and v4 MLS retrievals collected near Lhasa on 18 May 2012. These ozone profiles correspond to the temperature profiles shown in Fig. 3 and the water vapour profiles shown in Fig. 7. The ozone profile, based on ECC measurements convolved to MLS pressure levels using the v3 averaging kernels, is almost identical to the one convolved to MLS pressure levels using the $\mathrm{v} 4$ averaging kernels, and both reduced-resolution profiles are consistent with the vertical structure of the underlying in situ measurements. By contrast, the v3 and v4 retrievals differ substantially from each other between 68 and $316 \mathrm{hPa}$, with biases of up to $\pm 40 \%$ relative to the ECC measurements that often change sign between v3 and v4. One of the goals of the MLS v4 development was to reduce the degree of unrealistic vertical structure reported in v3 UTLS ozone profiles. This was accomplished by splitting the retrieval of ozone away from that of other species (notably, carbon monoxide and nitric acid) and neglecting channels that the retrievals were unable to fit accurately.

Figure 11 shows mean, median and rms biases for MLS v3 and v4 retrievals of ozone volume mixing ratio relative to ECC measurements. The number of samples used to calculate these statistics varies from a minimum of 38 samples at $10 \mathrm{hPa}$ (37 for v3) to a maximum of 69 samples at $316 \mathrm{hPa}$ (67 for v3). Mean and median biases in ozone volume mixing ratio are positive or statistically indistinguishable from zero throughout the UTLS except for at $100 \mathrm{hPa}$ (where mean biases are $-30 \pm 13 \%$ in v 3 and $-21 \pm 9 \%$ in v 4 and median biases are $-20 \%$ in v3 and $-18 \%$ in v4). Positive biases through most of the stratosphere $(18-83 \mathrm{hPa})$ indicate 

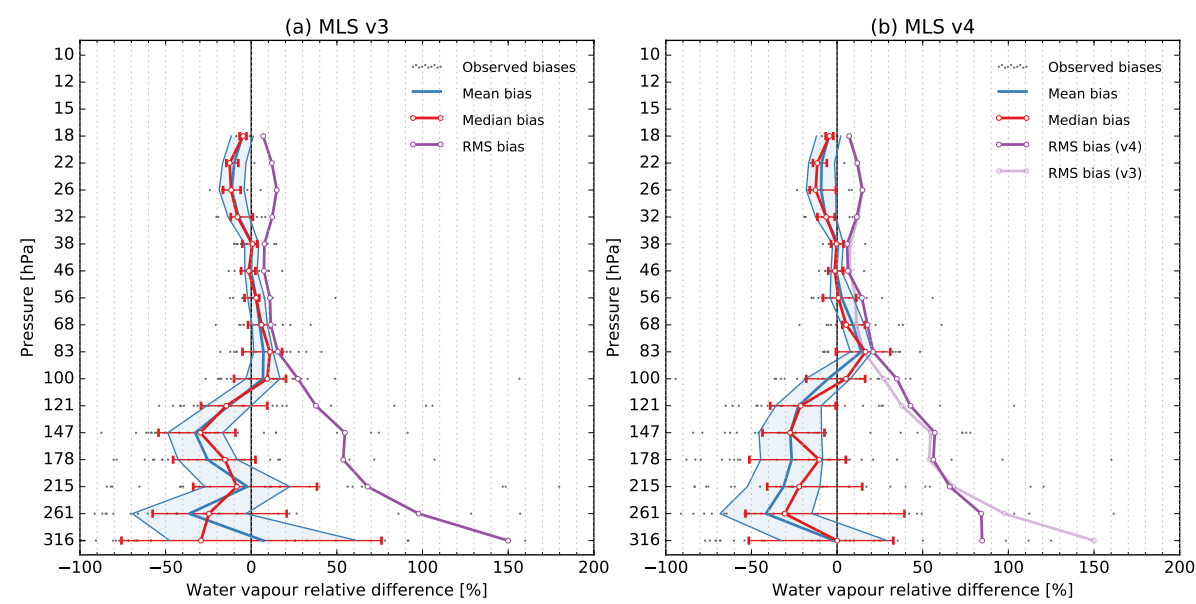

Figure 8. As in Fig. 4, but for relative biases between CFH and (a) MLS v3 and (b) MLS v4 profiles of water vapour volume mixing ratio. The mean and rms biases (and associated uncertainties) are calculated from absolute differences and then normalized relative to the mean CFH-derived mixing ratio at each level. The median bias and IQR are calculated using relative differences from each validation profile.

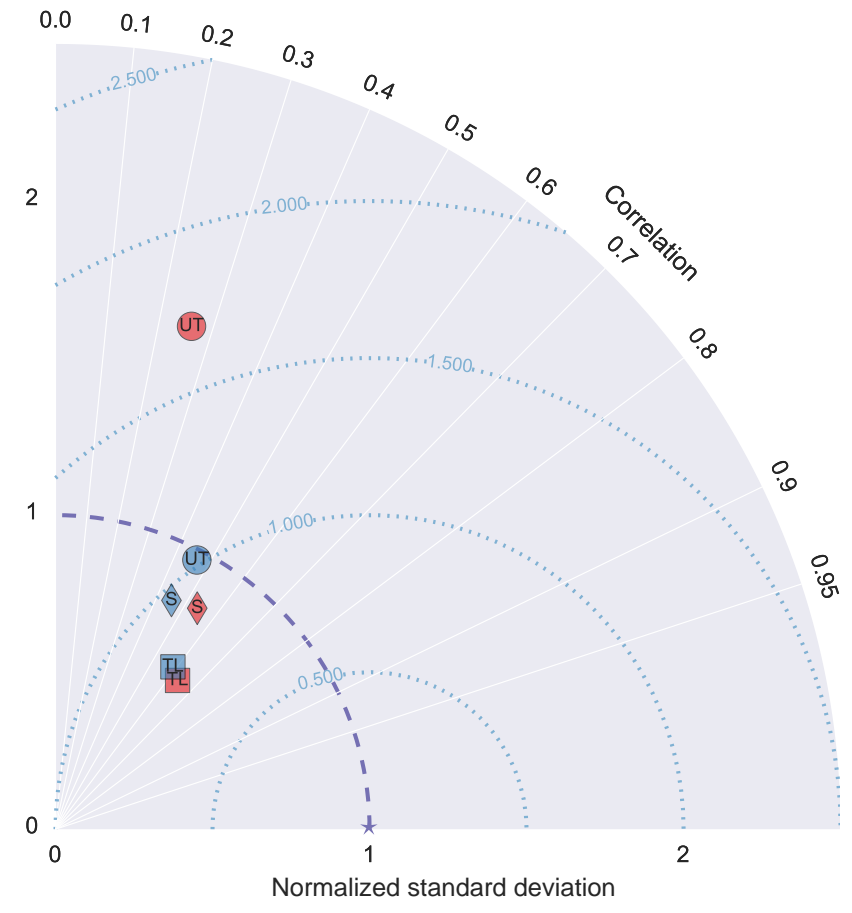

Figure 9. As in Fig. 5, but for water vapour. The UT in this case is defined as $178-316 \mathrm{hPa}$, rather than $178-261 \mathrm{hPa}$.

that MLS v3 and v4 generally overestimate ozone concentrations in this region during boreal summer. The maximum biases are located at $83 \mathrm{hPa}(72 \pm 11 \%$ in $\mathrm{v} 3 ; 63 \pm 10 \%$ in v4). This bias profile differs from bias profiles generated by comparisons with most ozonesonde profiles in this latitude range (Jiang et al., 2007) and by comparisons with other satellite data sets (Tegtmeier et al., 2013) and may be regionally/seasonally specific. In particular, the proximity of the balloon launch sites to the centre of the boreal summer

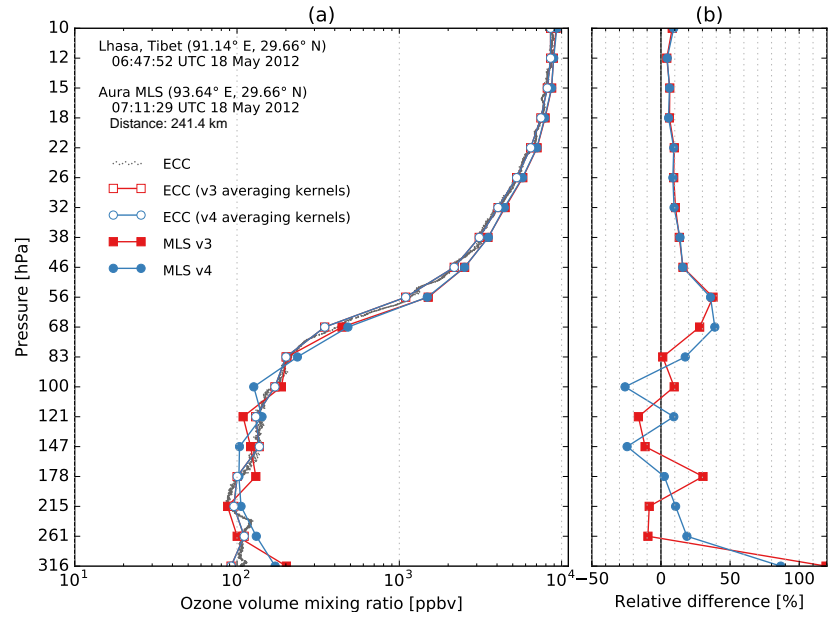

Figure 10. As in Fig. 3, but for ECC, MLS v3 and MLS v4 profiles of ozone volume mixing ratio.

lower stratospheric "ozone valley" (Zhou et al., 1995; Tobo et al., 2008) may contribute to the large positive biases at $83 \mathrm{hPa}$. We discuss this feature further in Sect. 4 .

Figure 12 and the lower rows of Table 2 summarize the validation statistics for ozone retrievals in three layers of the atmosphere chosen to represent the stratosphere (10-56 hPa), tropopause layer $(68-147 \mathrm{hPa})$ and upper troposphere (178$261 \mathrm{hPa}$ ). Observations at $316 \mathrm{hPa}$ are omitted from the upper troposphere layer average, as ozone retrievals at this layer are not recommended for scientific use in either v3 or v4. The pressure-weighted mean bias in the stratosphere is effectively the same in v3 and v4, while the pressure-weighted mean bias in the tropopause layer is much smaller in $\mathrm{v} 4$ than in v3. The pressure-weighted mean bias in the upper troposphere $(178-261 \mathrm{hPa})$ has changed from slightly negative in 

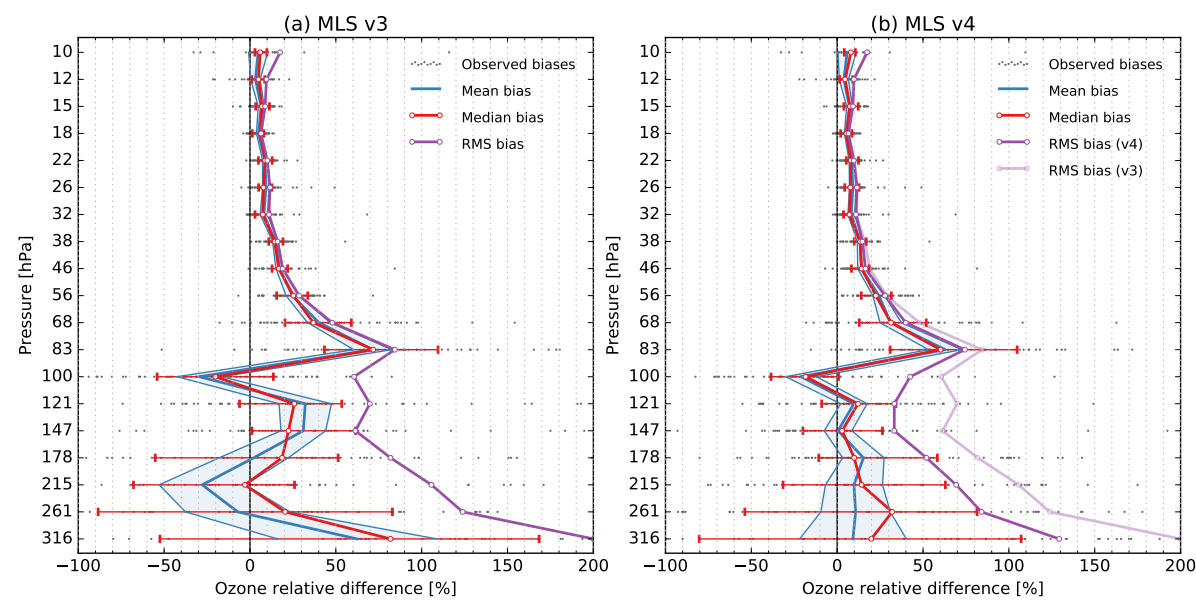

Figure 11. As in Fig. 4, but for relative biases between ECC and (a) MLS v3 and (b) MLS v4 profiles of ozone volume mixing ratio.

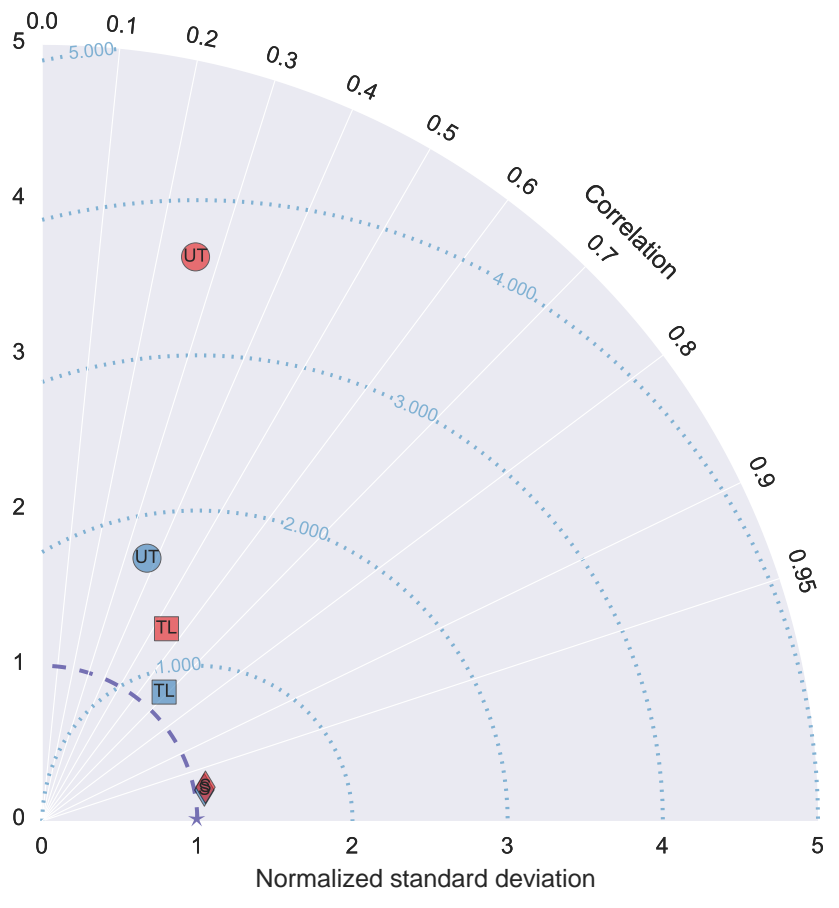

Figure 12. As in Fig. 5, but for ozone.

$\mathrm{v} 3$ to slightly positive in $\mathrm{v} 4$, along with a reduction in the associated standard error. This is consistent with smaller fluctuations in the vertical profile of the mean bias in v4 relative to v3, particularly at pressures greater than $100 \mathrm{hPa}$. Median biases are similar to mean biases through most of the UTLS. The consistency between mean and median biases in the stratosphere indicates that high biases in MLS ozone retrievals between 18 and $83 \mathrm{hPa}$ are robust to statistical assumptions: almost all $(\sim 92 \%)$ of the calculated biases in this layer are positive.

The vertical structure of rms biases in ozone mixing ratio largely mirrors the vertical structure of mean biases. The pressure-weighted mean rms biases in the upper troposphere and tropopause layer are smaller in $\mathrm{v} 4$ than in $\mathrm{v} 3$, with particularly pronounced improvements in the upper troposphere. Despite increased data yields (see Sect. 2.2), noise in upper tropospheric ozone retrievals appears to be substantially reduced in $\mathrm{v} 4$ relative to $\mathrm{v} 3$. Although ozone retrievals at $316 \mathrm{hPa}$ are still not recommended for scientific use (Livesey et al., 2015), our validation results indicate that these retrievals are much improved in $\mathrm{v} 4$.

MLS ozone retrievals are performed with respect to volume mixing ratio (unlike water vapour retrievals, which are performed with respect to the logarithm of volume mixing ratio). We therefore include a statistical evaluation of absolute biases in MLS v3 and v4 retrievals of ozone volume mixing ratio (Fig. 13) for context. Like the relative bias profiles, the absolute bias profiles are dominated by the high biases in the stratosphere, although the largest absolute biases are located at higher altitudes ( $38 \mathrm{hPa}$ and above) than the largest relative biases $(83 \mathrm{hPa})$. Pressure-weighted mean biases in the stratosphere are $378 \pm 56 \mathrm{ppbv}$ in $\mathrm{v} 3$ and $368 \pm 54$ ppbv in $\mathrm{v} 4$, pressure-weighted mean biases in the tropopause layer are $53 \pm 9$ ppbv in $\mathrm{v} 3$ and $35 \pm 8$ ppbv in $v 4$, and pressure-weighted mean biases in the upper troposphere are $-8 \pm 11$ ppbv in $\mathrm{v} 3$ and $8 \pm 7$ ppbv in $\mathrm{v} 4$.

\section{Discussion}

Aura is a sun-synchronous satellite, so that MLS observes the validation domain in the early morning $(\sim 01: 45$ local time, LT; descending passes $)$ and early afternoon $(\sim 13: 45 \mathrm{LT}$; ascending passes). Most of the retrievals selected for validation were daytime observations: approximately $65 \%$ of the temperature validation, $73 \%$ of the water vapour validation and $60 \%$ of the ozone validation are based on MLS retrievals made during ascending passes. We find no statistically significant differences between mean biases calcu- 

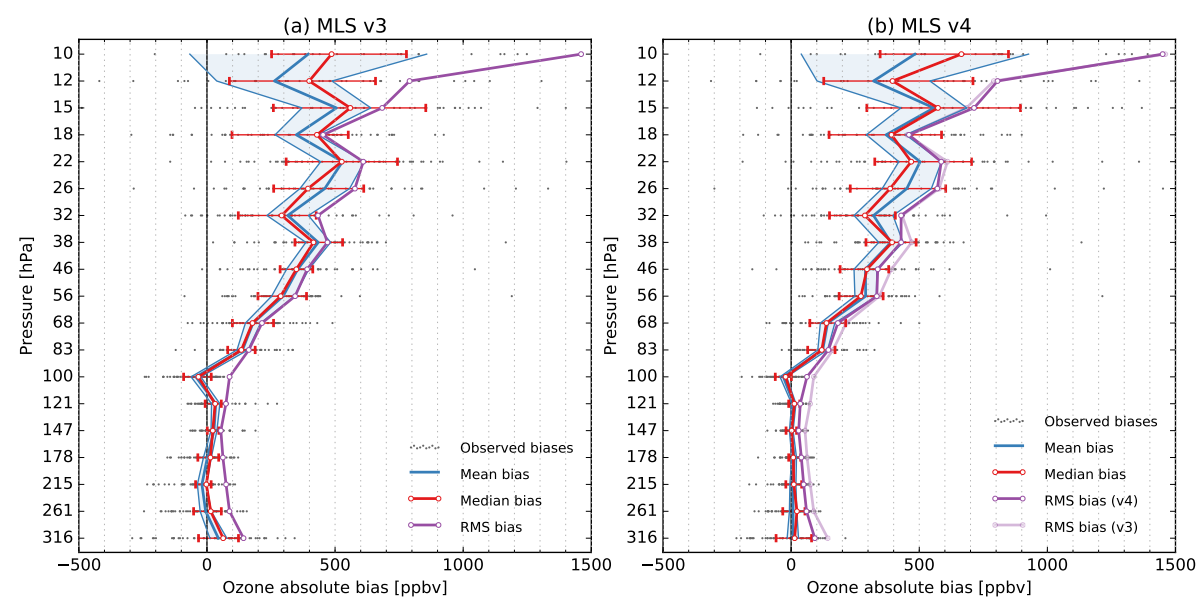

Figure 13. As in Fig. 4, but for absolute biases between ECC and (a) MLS v3 and (b) MLS v4 profiles of ozone volume mixing ratio.

lated for ascending retrievals and mean biases calculated for descending retrievals, with the exception of v3 temperature at two levels in the upper troposphere. Cold biases in v3 temperature retrievals at $178 \mathrm{hPa}$ are reduced during the daytime $(-1.1 \pm 0.5 \mathrm{~K})$ relative to night-time $(-2.4 \pm 0.7)$. This difference in mean biases persists up to $83 \mathrm{hPa}$, although the uncertainty windows overlap for pressures less than $178 \mathrm{hPa}$. By contrast, cold biases at $261 \mathrm{hPa}$ are enhanced during the daytime $(-3.5 \pm 0.9 \mathrm{~K})$ relative to nighttime $(-1.8 \pm 0.6)$. Cold biases at $316 \mathrm{hPa}$ are also enhanced for daytime retrievals $(-4.3 \pm 1.5 \mathrm{~K})$ relative to night-time retrievals $(-0.2 \pm 1.2 \mathrm{~K})$, with the caveat that these data are not recommended for use in scientific studies. Convective activity over the south-eastern Tibetan Plateau peaks in the late afternoon (Fujinami et al., 2005), so that these differences may be caused by convective activity or cloud contamination that is undetected by the quality control criteria. Alternatively, they may be attributable to systematic differences between the conditions over Linzhi in 2014 (where most of the sondes were launched at times corresponding to descending passes) and the other measurement sites in 2010-2012 (where most of the sondes were launched at times corresponding to ascending passes) or to biases in radiosonde temperature measurements caused by solar heating of the sensor (the so-called "radiation error"; Nash et al., 2011). Qualitatively similar differences are identified in the $v 4$ temperature validation, but these differences are not statistically significant.

The standard deviation, interquartile range and rms of temperature, water vapour and ozone biases generally increase with increasing pressure, indicating that the spread in the calculated biases is greatest in the upper troposphere. For example, standard deviations in $261 \mathrm{hPa}$ temperatures based on radiosonde observations range from $0.8 \mathrm{~K}$ (Tengchong) to $2.0 \mathrm{~K}$ (Naqu). Standard deviations in $261 \mathrm{hPa}$ temperatures based on retrievals within $200 \mathrm{~km}$ of the measurement sites during the measurement campaigns are much larger, ranging from $2.5 \mathrm{~K}$ (Naqu) to $5.5 \mathrm{~K}$ (Lhasa) in $\mathrm{v} 3$ and from
3.0 K (Naqu) to $4.7 \mathrm{~K}$ (Tengchong) in v4. Further analysis of our validation results shows strong correlations between the magnitude of the calculated bias and the value retrieved by MLS in the upper troposphere and tropopause layer, particularly for temperature and ozone (not shown). These correlations are uniformly positive, indicating that the variance in the collocated MLS retrievals is larger than the variance in the in situ measurements (i.e. that the in situ measurements are more tightly clustered around the mean value). The correlation coefficients between temperature retrievals and biases and between ozone retrievals and biases increase with increasing pressure, indicating that larger variance in the MLS retrievals is the primary source of the larger spread in the calculated biases. The primary implication is that MLS-based estimates of temperature, water vapour and ozone in the upper troposphere are more reliable at monthly and seasonal timescales than at event timescales, where excessive noise can result in biases at several layers within the UTLS.

Excess variance in the MLS retrievals relative to the in situ measurements can arise from several sources and is not necessarily spurious. These sources include increasing uncertainty and noise (due to greater attenuation of the radiance signals used in the MLS retrievals and potential contamination by ice particles in the upper troposphere), but also the increasing influence of spatio-temporal variability. Spatiotemporal variability in the composition and thermodynamic structure of the upper troposphere may be related to variations in deep convective activity, wave activity, the location of the upper tropospheric anticyclone and other meteorological and climatological features. Many of these variations can be considered approximately random from the perspective of regular sampling at a fixed location, with effects that will be reflected in the variance of the MLS measurements and the spread around the mean bias, but will be negligible with respect to the mean itself. However, variations associated with seasonal climatological features (such as the mean position of the upper tropospheric anticyclone) or features that are 
unrepresented in the in situ data (such as active convection, which precludes radiosonde launch) may manifest as systematic biases.

The UTLS over the summertime Asian monsoon contains sharp horizontal gradients in temperature, water vapour and ozone (Randel and Park, 2006; Park et al., 2007). Preferential sampling of collocated MLS retrievals upgradient of the measurement sites would result in an apparent high bias, while preferential sampling of retrievals downgradient of the measurement sites would result in an apparent low bias. For example, the in situ measurements used to validate MLS retrievals in this study were collected near the "ozone valley" that develops in the UTLS during the Asian summer monsoon (Zhou et al., 1995; Tobo et al., 2008). This regionalscale minimum in column ozone is a result of repeated injection of ozone-poor air by monsoon convection (potentially augmented by chemical depletion in the tropopause layer) and propagates upward as part of the large-scale ascent associated with the monsoon anticyclone.

Figure 14 shows time-mean gridded spatial distributions of ozone at $83 \mathrm{hPa}$ based on MLS v4 retrievals during the four measurement campaigns. The time-mean location and magnitude of the ozone minimum varied substantially among the measurement campaigns, but the local minimum was consistently located nearby to the measurement sites. Slightly more than a third of the MLS retrievals collocated with our ozonesonde profiles were based on observations at locations with similar time mean values to the measurement sites, but more of the retrievals were located upgradient (43\% at locations with higher time-mean ozone concentrations) than were located downgradient ( $22 \%$ at locations with lower timemean ozone concentrations). The mean difference between the time-mean values at the upgradient sites and the timemean values at the launch sites $(+26 \%)$ was also more than double the mean difference between the time-mean values at the downgradient sites and the time-mean values at the launch sites $(-12 \%)$. These results suggest that some portion of the high bias in MLS ozone at $83 \mathrm{hPa}$ may be due to spatial sampling biases.

To more fully evaluate the possibility that preferential spatial sampling produces a high bias in MLS ozone at $83 \mathrm{hPa}$, we interpolate time-mean gridded MLS profiles to each measurement site using bilinear interpolation (the results are virtually identical when higher-order interpolation schemes are used). We then compare these time-mean interpolated profiles with the average values of the in situ observations collected during the associated measurement campaign. The results are shown in Fig. 15. The shape of the bias profile is qualitatively robust. Moreover, the mean bias at $83 \mathrm{hPa}$ appears to accurately capture the local biases at Tengchong and Linzhi but underestimates the local biases at Naqu and Lhasa. Weighting the results by the number of profiles at each site, the mean interpolated bias is $87 \%$ for v 3 and $82 \%$ for v4. These values are larger than the mean biases calculated in Sect. $3.3(70 \pm 11 \%$ for v3 and $66 \pm 10 \%$ for v4).
We therefore find little evidence that systematic errors arising from preferential spatial sampling could cause us to overestimate the high bias in MLS ozone mixing ratios at $83 \mathrm{hPa}$. A more plausible explanation may be propagation of information from the a priori profile into the retrieval, in particular through the smoothing constraints in the MLS retrieval algorithms, which favour retrieved profiles with shapes (characterized by the vertical second derivative) close to that of the a priori. The MLS a priori profiles (which are taken from monthly zonal mean model output) begin to increase at a lower altitude with a more gradual vertical gradient in the tropopause layer than is typically observed over this region during the monsoon (Fig. 16; see also Bian et al., 2012; Yan et al., 2015). This hypothesis is provisionally supported by a significant reduction in biases at $83 \mathrm{hPa}$ calculated using observations made at Lhasa and Linzhi before monsoon onset $(44 \pm 14 \%$ in $v 3 ; 26 \pm 15 \%$ in $v 4)$ relative to during the monsoon $(82 \pm 15 \%$ in $v 3 ; 78 \pm 12 \%$ in v4), as well as the fact that (to our knowledge) no previous MLS ozone validation effort has identified such a sharp peak in the ozone bias profile at $83 \mathrm{hPa}$. Sensitivity testing has shown that MLS retrievals are largely insensitive to constant offsets in the a priori profiles; however, the impacts of shifting tropopause-related gradients and other sharp features vertically within the a priori profiles have not yet been examined.

Temperature within the Asian monsoon anticyclone is warm relative to the zonal mean in the upper troposphere and cold relative to the zonal mean in the tropopause layer (Park et al., 2007). A broad temperature maximum was located to the west of the measurement sites in the upper troposphere (178-261 hPa), but time-mean temperature contours above the measurement sites were approximately zonal at $147 \mathrm{hPa}$ and above. Despite some regional differences, biases between time-mean temperature profiles interpolated to each measurement site and mean temperature profiles based on radiosonde observations at the corresponding measurement site (not shown) are comparable in both structure and magnitude to the mean and median biases shown in Fig. 4. The vertical structure of temperature biases before monsoon onset is similar to that during the monsoon; however, cold biases in the stratosphere are slightly enhanced (by $\sim 0.5-1 \mathrm{~K}$ ) before monsoon onset relative to during the monsoon, while cold biases in the upper troposphere are slightly enhanced (by $\sim 1-1.5 \mathrm{~K}$ ) during the monsoon relative to before monsoon onset. At 100-121 hPa, cold biases before the monsoon $(-0.8 \pm 0.6 \mathrm{~K}$ in $\mathrm{v} 3 ;-1.3 \pm 0.5 \mathrm{~K}$ in $\mathrm{v} 4)$ are replaced by warm biases during the monsoon $(0.9 \pm 0.6 \mathrm{~K}$ in $\mathrm{v} 3 ; 0.7 \pm 0.6 \mathrm{~K}$ in $\mathrm{v} 4)$. These quantitative changes in temperature bias oppose the changes in temperature structure that accompany monsoon onset (warming in the upper troposphere and cooling near the tropopause) and indicate that MLS underestimates seasonal changes in UTLS temperature associated with the establishment of the Asian monsoon anticyclone.

The measurement sites are also located in the vicinity of sharp gradients in water vapour, with a broad maximum in 

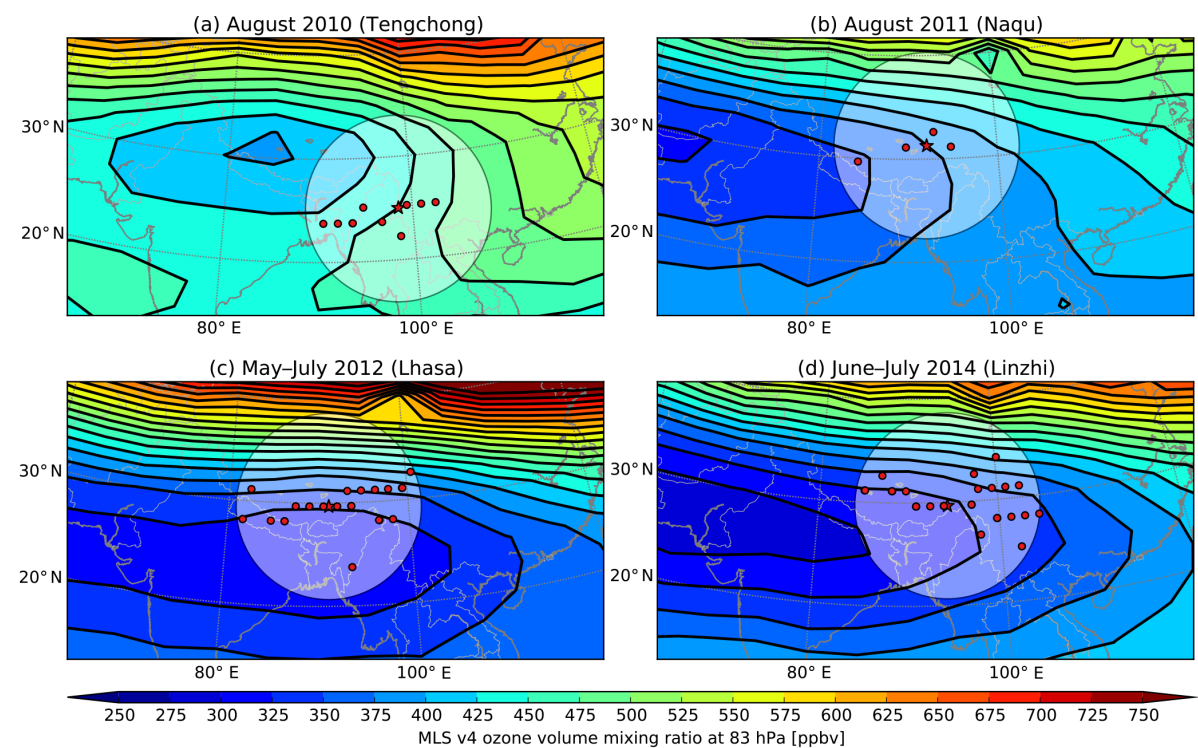

Figure 14. Balloon launch locations (red stars), centres of footprints of MLS observations collocated to balloons launched at each location (red circles) and mean spatial distributions of ozone volume mixing ratio at the $83 \mathrm{hPa}$ level during the measurement campaigns at (a) Tengchong, Yunnan in August 2010, (b) Naqu, Tibet in August 2011, (c) Lhasa, Tibet in May-July 2012 and (d) Linzhi, Tibet in June-July 2014. The gridded values are inverse-distance weighted averages on a $5^{\circ}$ longitude by $2.5^{\circ}$ latitude grid, with weighted contributions from all valid measurements within $10^{\circ}$ longitude and $10^{\circ}$ latitude of the grid cell centre.
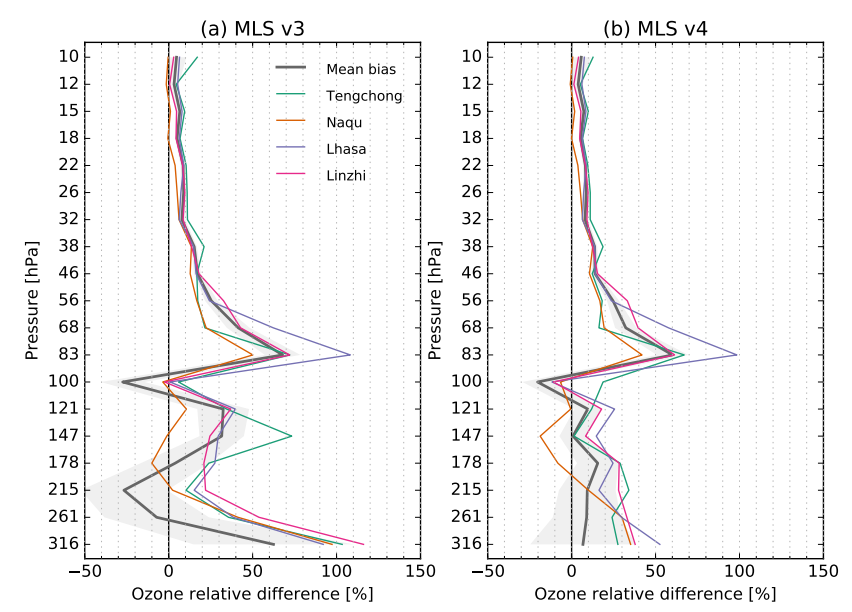

Figure 15. Relative differences between ECC ozonesonde observations and retrievals of ozone volume mixing ratio from (a) MLS v3 and (b) MLS v4. Grey lines and shading represent the mean bias and twice the standard error of the mean bias from the core validation analysis, as shown in Fig. 11. Coloured lines represent relative differences between mean ozonesonde observations convolved to MLS pressure levels and time-mean gridded MLS observations during each study period (see, e.g. Fig. 14) interpolated to the respective ozonesonde launch site.

the upper troposphere and tropopause layer that transitions to an approximate south-north gradient in the stratosphere. The maximum in the upper troposphere is generally centred over the Bay of Bengal, south of the measurement sites, while

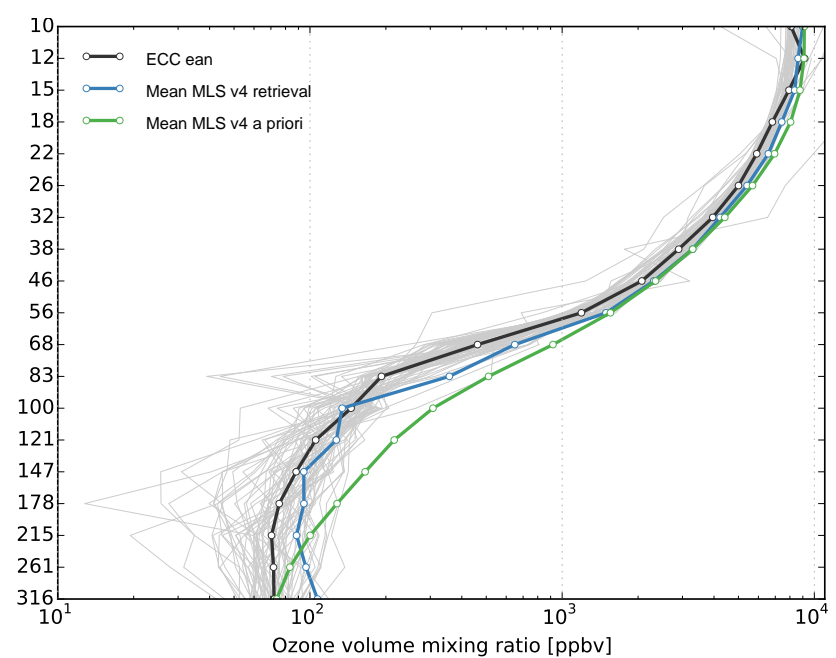

Figure 16. Vertical profiles of ozone mixing ratio from ECC profiles convolved to MLS pressure levels (mean in dark grey; individual profiles in light grey), MLS v4 retrievals in the validation domain (blue) and MLS v4 a priori profiles in the validation domain (green).

the maximum in the tropopause layer is centred over the southern slope of the Tibetan Plateau, almost directly above the measurement sites. A comparison of mean $\mathrm{CFH}$ profiles and time-mean MLS profiles interpolated to each measurement site (not shown) reveals regional variability, but no systematic differences relative to the mean bias profile shown in Fig. 8. The combined regional biases are similar to the 
mean and median bias profiles discussed in Sect. 3.2. With the exception of $316 \mathrm{hPa}$ in $\mathrm{v} 3$, standard deviations in MLS retrievals within $200 \mathrm{~km}$ of the measurement sites are comparable to (and sometimes even smaller than) standard deviations in the CFH measurements convolved to MLS pressure levels. Combined with the lack of strong correlations between water vapour retrievals and biases, this quantitative similarity indicates that the increase in the spread of water vapour biases with increasing pressure may be attributable to real variability with timescales/space scales similar to or smaller than the collocation criteria, rather than noise in the retrievals. We conclude that MLS provides a reliable representation of water vapour mixing ratios in the UTLS over this region with respect to both mean values (mean biases within $\pm 20 \%$ ) and variance (although MLS v4 may underestimate the real variability of water vapour in the upper troposphere between 215 and $261 \mathrm{hPa}$, where standard deviations in MLS retrievals are less than $50 \%$ of the standard deviations in the $\mathrm{CFH}$ measurements). Retrievals of water vapour mixing ratios at $316 \mathrm{hPa}$ are generally improved in $\mathrm{v} 4$ relative to $\mathrm{v} 3$, particularly in terms of variance (which is comparable to $\mathrm{CFH}$-derived variance in v4, but approximately double $\mathrm{CFH}$ derived variance in $\mathrm{v} 3$ ). We find no significant differences in water vapour biases before monsoon onset relative to during the monsoon.

MLS v3 temperature and ozone retrievals at $316 \mathrm{hPa}$ are not recommended for scientific use due to excessive noise, large biases and insufficient validation (Livesey et al., 2013, 2015); we now revisit these recommendations in the context of our results. The results of our validation analysis (Fig. 4) show a slight decrease in the mean $(-2.9 \pm 1.1$ to $-2.7 \pm 1.5 \mathrm{~K})$ and median $(-2.8$ to $-1.8 \mathrm{~K})$ temperature biases at $316 \mathrm{hPa}$ in $\mathrm{v} 4$ relative to $\mathrm{v} 3$, although these changes are not statistically significant. By contrast, there are strong indications that $\mathrm{v} 4$ temperature retrievals are noisier than $\mathrm{v} 3$ temperature retrievals at this level, as indicated by increases in the rms bias (from 5.9 to $7.5 \mathrm{~K}$ ), the standard error of the mean bias (from 0.6 to $0.8 \mathrm{~K}$ ) and the extent of the interquartile range around the median bias (from 6.2 to $10.5 \mathrm{~K}$ ). Users of $v 4$ should continue to avoid the use of temperature retrievals at $316 \mathrm{hPa}$ in scientific studies. Moreover, enhanced noise in v4 temperature retrievals (relative to v3) extends upward to $178 \mathrm{hPa}$, indicating that users of MLS retrievals of upper tropospheric temperature should exercise care before using v4 (especially for studies of individual events). By contrast, our validation of MLS ozone retrievals (Fig. 11) shows a sharp reduction in the mean bias of ozone volume mixing ratio at $316 \mathrm{hPa}$ in $\mathrm{v} 4(10 \pm 30 \%)$ relative to $\mathrm{v} 3(67 \pm 47 \%)$, along with reductions in rms (from $204 \%$ in v3 to $128 \%$ in v4) and median (from $82 \%$ in v3 to $29 \%$ in v4) biases. Although ozone retrievals at this level remain noisy and additional evaluation is still needed, our results indicate that $\mathrm{v} 4$ represents a substantial improvement in ozone retrievals at $316 \mathrm{hPa}$ (and throughout the upper troposphere) relative to v3.
Yan et al. (2015) presented a preliminary validation of MLS v2 and v3 water vapour and ozone retrievals using many of the soundings collected at Tengchong, Naqu and Lhasa. Our methodology differs from theirs in several respects, most notably in the approach used for convolving the sonde profiles to MLS levels (where we use the MLS averaging kernels and forward smoothing function as opposed to linear interpolation) and in the criteria used to select coincident MLS retrievals for validation. Moreover, the inclusion of additional soundings (particularly those collected at around midnight local time over Linzhi) substantially reduces uncertainty windows around the mean and median biases and allows for a more comprehensive validation of retrievals collected during both ascending and descending satellite overpasses. The key features of the water vapour and ozone bias profiles are robust despite these differences in methodology, particularly the high biases in lower stratospheric ozone.

\section{Summary and outlook}

Aura MLS v3 and v4 retrievals of temperature, water vapour and ozone provide valuable information about the thermal structure and composition of the upper troposphere and stratosphere in the Asian monsoon anticyclone. We have presented a validation of these data in the UTLS $(10-316 \mathrm{hPa})$ using in situ measurements collected using balloon-borne instruments over the Tibetan Plateau (Naqu, Lhasa and Linzhi) and adjacent regions (Tengchong, Yunnan) during four recent summers.

Temperature biases are largely similar between $\mathrm{v} 3$ and $\mathrm{v} 4$, with slightly smaller cold biases in $\mathrm{v} 4$ in the tropopause layer $(68-147 \mathrm{hPa})$ and lower-middle stratosphere $(10-56 \mathrm{hPa})$, but slightly larger cold biases in $\mathrm{v} 4$ in the upper troposphere $(178-261 \mathrm{hPa})$. Vertical oscillations in the temperature bias profile that have existed since the initial public release (Schwartz et al., 2008) persist in v4. Retrievals at $316 \mathrm{hPa}$ remain unsuitable for use in scientific studies, while increased variance in $\mathrm{v} 4$ throughout the upper troposphere (178-261 hPa) may create issues for studies focused on individual events or using small sample sizes. Variances in MLS retrievals are several Kelvin larger than variances derived from radiosonde profiles, especially in the upper troposphere, reflecting the effects of noise on the retrievals. The upper troposphere over the validation domain is systematically colder by $0.2-0.8 \mathrm{~K}$ in $\mathrm{v} 4$ relative to $\mathrm{v} 3$, while changes to the retrieval algorithm and quality control criteria increase the data yield in this region by about $10 \%$.

Biases in v3 and v4 water vapour retrievals in the stratosphere are also largely similar to each other, with a slightly smaller dry bias near $22-26 \mathrm{hPa}$ and a slightly larger moist bias near $68-83 \mathrm{hPa}$. The vertical profile of mean biases between 121 and $261 \mathrm{hPa}$ is more homogeneous in $\mathrm{v} 4$ than in $\mathrm{v} 3$, but at the cost of larger dry biases in v4 at $215 \mathrm{hPa}$. MLS 
$\mathrm{v} 4$ retrievals of water vapour through much of the upper troposphere are 30-40\% drier than collocated CFH measurements. This dry bias is more vertically homogeneous than previous estimates from other regions based on comparison with CFH measurements (which found mean moist biases at $261 \mathrm{hPa}$ Read et al., 2007; Vömel et al., 2007a) and considerably larger than estimates based on comparison with other satellite retrievals in the tropical or extratropical mean (Hegglin et al., 2013). Biases of rms and other variance estimates are slightly larger between 56 and $178 \mathrm{hPa}$ in v4 than in v3, perhaps due to large increases $(\sim 32 \%)$ in data yield from $v 3$ to v4. By contrast, variance is substantially reduced at 261 and $316 \mathrm{hPa}$ and is now largely consistent with estimates of variance derived from the $\mathrm{CFH}$ measurements.

Ozone retrievals are substantially improved in $\mathrm{v} 4$ relative to v3, particularly in the upper troposphere and tropopause layer: biases in ozone retrievals in the tropopause layer are significantly smaller, variance is reduced below $68 \mathrm{hPa}$ (along with a $29 \%$ increase in data yield), and sharp gradients in the vertical profile of ozone biases in the upper troposphere are largely eliminated. The most influential change in ozone is a reduction of the vertical gradient of ozone mixing ratio between 100 and $316 \mathrm{hPa}$, which includes decreases in ozone mixing ratios in the tropopause layer $(83-147 \mathrm{hPa})$ and in the lower part of the upper troposphere $(261-316 \mathrm{hPa})$. Despite these improvements, MLS ozone retrievals are biased high relative to ECC measurements through most of the stratosphere $(18-83 \mathrm{hPa})$ and biased low relative to ECC measurements at $100 \mathrm{hPa}$. Of particular note, the bias profile contains a pronounced peak of about $+70 \%$ at $83 \mathrm{hPa}$, which is not seen in biases relative to measurements made at most other ozonesonde sites (Jiang et al., 2007) or retrievals made by other satellite instruments (Tegtmeier et al., 2013). This large positive bias at $83 \mathrm{hPa}$ may therefore be specific to ozone retrievals in the vicinity of the Asian monsoon anticyclone. Detailed analysis indicates that this bias is unlikely to result from preferential sampling of higher ozone mixing ratios upgradient from the nearby "ozone valley". We propose instead that this persistent high bias may propagate into the retrieval via smoothing towards the a priori profile, which does not adequately represent the very sharp vertical gradient in ozone concentrations near the tropopause over this region.
Overall, our validation indicates that v4 represents an improvement on $\mathrm{v} 3$. This improvement is particularly apparent for ozone, but is also manifest in increased data yields and small improvements in the bias profiles for temperature (at $147 \mathrm{hPa}$ and above) and water vapour. Temperature retrievals in the upper troposphere $(178-261 \mathrm{hPa})$ are more problematic, as v4 shows a larger cold bias and larger variance than $\mathrm{v} 3$ at these levels.

Several aspects of our results differ from previously published estimates of global and tropical biases in MLS retrievals, including the structure and magnitude of high biases in ozone through much of the stratosphere (which are substantially larger than previous estimates, particularly at 68-83 hPa Jiang et al., 2007; Tegtmeier et al., 2013), the magnitude of dry biases in the upper troposphere (which are slightly larger and more vertically homogeneous than previous estimates; Read et al., 2007; Hegglin et al., 2013) and the magnitude of cold biases in the upper troposphere (which are also larger than previous estimates, particularly in v4 Schwartz et al., 2008; Livesey et al., 2015). Of these, the unusually large high bias in ozone at $83 \mathrm{hPa}$ and the unusually large cold bias in the upper troposphere are exacerbated following monsoon onset. Conditions in the Asian monsoon anticyclone pose unique challenges for remote sensing that impact the quality of MLS retrievals in this region. These results provide valuable context that will help to facilitate future studies of the thermal structure and composition of the UTLS in the Asian monsoon anticyclone and are expected to contribute to future improvements in the MLS retrieval algorithm and data products in this critical region of the atmosphere.

\section{Data availability}

MLS data were obtained from the Atmospheric Composition Data and Information Services Center FTP archive (ftp://acdisc.gsfc.nasa.gov) hosted by NASA Goddard Space Flight Center. Balloonsonde profiles convolved with MLS averaging kernels are available upon request. 


\section{Appendix A: Quality control criteria}

In addition to the collocation criteria (within $1000 \mathrm{~km}$ and $\pm 12 \mathrm{~h}$ ), we have selected only high-quality MLS retrievals for validation. Livesey et al. (2013) and Livesey et al. (2015) recommended quality control criteria for $\mathrm{v} 3$ and $\mathrm{v} 4$ respectively. We slightly modify their recommendations to ensure that all profiles selected for comparison are valid throughout the $316-10 \mathrm{hPa}$ vertical range. These modifications result in more restrictive criteria, at the potential cost of selecting retrievals that are farther from the balloonsonde launch site than the closest viable retrieval at some levels. The quality control criteria we use are reproduced below for convenience; readers requiring further details should refer to Livesey et al. (2013) or Livesey et al. (2015).

\section{A1 Temperature}

For v3 temperature, the Convergence flag must be less than 1.2, the Quality flag must be greater than 0.65 , the Status flag must be even, the fifth (low cloud) bit of the Status flag must not be set for either of the following two retrievals in the orbit and L2gpPrecision must be positive at all levels between 316 and $10 \mathrm{hPa}$.

For v4 temperature, the Convergence flag must be less than 1.03, the Quality flag must be greater than 0.9, the Status flag must be even, the MLS-retrieved ice water content (IWC) at $215 \mathrm{hPa}$ must be less than $0.005 \mathrm{mg} \mathrm{m}^{-3}$ and L 2 gpP recision must be positive at all levels between 316 and $10 \mathrm{hPa}$ and must be less than or equal to 0.7 at $261 \mathrm{hPa}$ and 0.825 at $215 \mathrm{hPa}$.

\section{A2 Water vapour}

For v3 water vapour, the Convergence flag must be less than 2.0, the Quality flag must be greater than 1.3, the Status flag must be even, the fourth (high cloud) and fifth (low cloud) bits of the Status flag must not be set and L2gpPrecision must be positive at all levels between 316 and $10 \mathrm{hPa}$.

For v4 water vapour, the Convergence flag must be less than 2.0, the Quality flag must be greater than 1.45, the Status flag must be even and L 2 gpPrecision must be positive at all levels between 316 and $10 \mathrm{hPa}$.

\section{A3 Ozone}

For v3 ozone, the Convergence flag must be less than 1.18 , the Quality flag must be greater than 0.6 , the Status flag must be even, L2gpPrecision must be positive at all levels between 316 and $10 \mathrm{hPa}$ and L2gpValue must be greater than $-0.3 \times 10^{-6}$ at $316 \mathrm{hPa}$ and greater than $-0.15 \times 10^{-6}$ at all other levels. Occasional negative values in the ozone retrievals are caused by low signal-to-noise ratios (likely due to low ozone mixing ratios in the troposphere). The inclusion of these negative values is necessary to avoid high biases in measures of the statistical centre and low biases in measures of statistical spread (Livesey et al., 2015).

For v4 ozone, the Convergence flag must be less than 1.03 , the Quality flag must be greater than 1.0 , the Status flag must be even and L2gpPrecision must be positive at all levels between 316 and $10 \mathrm{hPa}$. 
Acknowledgements. Support for the balloon soundings at Tengchong was provided by the National Natural Science Foundation of China under grant 40875014. Support for the balloon soundings at Naqu, Lhasa and Linzhi was provided the Special Fund for Meteorological Research in the Public Interest under grant GYHY201106023 and the Science and Technological Innovation Team Project of Chinese Academy of Meteorological Science under grants $2011 Z 003$ and 2013Z005. The validation analysis was supported by a Young Thousand Talents fellowship at Tsinghua University. The measurement campaigns were supported by the Tengchong Meteorological Bureau in Yunnan and the Naqu Meteorological Bureau, Lhasa Meteorological Bureau and Linzhi Meteorological Bureau in Tibet. Work at the Jet Propulsion Laboratory, California Institute of Technology was performed under a contract with the National Aeronautics and Space Administration. We thank Michelle Santee, Irina Gerasimov and James E. Johnson for facilitating early access to the MLS version 4 data; Yonghong $\mathrm{Ma}$ and Yong Zhang from the Tibet Meteorological Bureau; Weiguo Wang from Yunnan University and the staff members of Kunming Observatory; Kejia Jia at the Linzhi Meteorological Bureau; and Wei Li, Jianyang Song, Jin Ma and Shumeng Sun from the Chinese Academy of Meteorological Sciences.

Edited by: T. Wagner

Reviewed by: two anonymous referees

\section{References}

Berthet, G., Renard, J.-B., Ghysels, M., Durry, G., Gaubicher, B., and Amarouche, N.: Balloon-borne observations of midlatitude stratospheric water vapour: comparisons with HALOE and MLS satellite data, J. Atmos. Chem., 70, 197-219, doi:10.1007/s10874-013-9264-7, 2013.

Bian, J., Pan, L. L., Paulik, L., Vömel, H., Chen, H., and Lu, D.: In situ water vapor and ozone measurements in Lhasa and Kunming during the Asian summer monsoon, Geophys. Res. Lett., 39, L19808, doi:10.1029/2012GL052996, 2012.

Dessler, A. E., Schoeberl, M. R., Wang, T., Davis, S. M., and Rosenlof, K. H.: Stratospheric water vapor feedback, P. Natl. Acad. Sci. USA, 110, 18087-18091, doi:10.1073/pnas.1310344110, 2013.

Froidevaux, L., Livesey, N. J., Read, W. G., Jiang, Y. B., Jimenez, C., Filipiak, M. J., Schwartz, M. J., Santee, M. L., Pumphrey, H. C., Jiang, J. H., Wu, D. L., Manney, G. L., Drouin, B. J., Waters, J. W., Fetzer, E. J., Bernath, P. F., Boone, C. D., Walker, K. A., Jucks, K. W., Toon, G. C., Margitan, J. J., Sen, B., Webster, C. R., Christensen, L. E., Elkins, J. W., Atlas, E., Lueb, R. A., and Hendershot, R.: Early validation analyses of atmospheric profiles from EOS MLS on the Aura satellite, IEEE T. Geosci. Remote Sens., 44, 1106-1121, 2006.

Fu, R., Hu, Y., Wright, J. S., Jiang, J. H., Dickinson, R. E., Chen, M., Filipiak, M., Read, W. G., Waters, J. W., and Wu, D. L.: Short circuit of water vapor and polluted air to the global stratosphere by convective transport over the Tibetan Plateau, P. Natl. Acad. Sci. USA, 103, 5664-5669, 2006.

Fujinami, H., Nomura, S., and Yasunari, T.: Characteristics of diurnal variations in convection and precipitation over the southern Tibetan Plateau during summer, SOLA, 1, 49-52, doi:10.2151/sola.2005-014, 2005.

Goff, J. A. and Gratch, S.: Low-pressure properties of water from -160 to $212^{\circ}$ F, Trans. Am. Soc. Heating Ventilating Eng., 52, 95-122, 1946.

Hegglin, M. I., Tegtmeier, S., Anderson, J., Froidevaux, L., Fuller, R., Funke, B., Jones, A., Lingenfelser, G., Lumpe, J., Pendlebury, D., Remsberg, E., Rozanov, A., Toohey, M., Urban, J., von Clarmann, T., Walker, K. A., Wang, R., and Weigel, K.: SPARC Data Initiative: Comparison of water vapor climatologies from international satellite limb sounders, J. Geophys. Res. Atmos., 118, 11824-11846, doi:10.1002/jgrd.50752, 2013.

Hurst, D. F., Hall, E. G., Jordan, A. F., Miloshevich, L. M., Whiteman, D. N., Leblanc, T., Walsh, D., Vömel, H., and Oltmans, S. J.: Comparisons of temperature, pressure and humidity measurements by balloon-borne radiosondes and frost point hygrometers during MOHAVE-2009, Atmos. Meas. Tech., 4, 2777-2793, doi:10.5194/amt-4-2777-2011, 2011.

Hurst, D. F., Lambert, A., Read, W. G., Davis, S. M., Rosenlof, K. H., Hall, E. G., Jordan, A. F., and Oltmans, S. J.: Validation of Aura Microwave Limb Sounder stratospheric water vapor measurements by the NOAA frost point hygrometer, J. Geophys. Res.-Atmos., 119, 1612-1625, doi:10.1002/2013JD020757, 2014.

Jiang, Y. B., Froidevaux, L., Lambert, A., Livesey, N. J., Read, W. G., Waters, J. W., Bojkov, B., Leblanc, T., McDermid, I. S., Godin-Beekmann, S., Filipiak, M. J., Harwood, R. S., Fuller, R. A., Daffer, W. H., Drouin, B. J., Cofield, R. E., Cuddy, D. T., Jarnot, R. F., Knosp, B. W., Perun, V. S., Schwartz, M. J., Snyder, W. V., Stek, P. C., Thurstans, R. P., Wagner, P. A., Allaart, M., Andersen, S. B., Bodeker, G., Calpini, B., Claude, H., Coetzee, G., Davies, J., Backer, H. D., Dier, H., Fujiwara, M., Johnson, B., Kelder, H., Leme, N. P., König-Langlo, G., Kyro, E., Laneve, G., Fook, L. S., Merrill, J., Morris, G., Newchurch, M., Oltmans, S., Parrondos, M. C., Posny, F., Schmidlin, F., Skrivankova, P., Stubi, R., Tarasick, D., Thompson, A., Thouret, V., Viatte, P., Vömel, H., Gathen, P. G., Yela, M., and Zablocki, G.: Validation of Aura Microwave Limb Sounder Ozone by ozonesonde and lidar measurements, J. Geophys. Res.-Atmos., 112, D24S34, doi:10.1029/2007JD008776, 2007.

Lambert, A., Read, W. G., Livesey, N. J., Santee, M. L., Manney, G. L., Froidevaux, L., Wu, D. L., Schwartz, M. J., Pumphrey, H. C., Jimenez, C., Nedoluha, G. E., Cofield, R. E., Cuddy, D. T., Daffer, W. H., Drouin, B. J., Fuller, R. A., Jarnot, R. F., Knosp, B. W., Pickett, H. M., Perun, V. S., Snyder, W. V., Stek, P. C., Thurstans, R. P., Wagner, P. A., Waters, J. W., Jucks, K. W., Toon, G. C., Stachnik, R. A., Bernath, P. F., Boone, C. D., Walker, K. A., Urban, J., Murtagh, D., Elkins, J. W., and Atlas, E.: Validation of the Aura Microwave Limb Sounder middle atmosphere water vapor and nitrous oxide measurements, J. Geophys. Res.Atmos., 112, D24S36, doi:10.1029/2007JD008724,2007.

Livesey, N. J., Filipiak, M. J., Froidevaux, L., Read, W. G., Lambert, A., Santee, M. L., Jiang, J. H., Pumphrey, H. C., Waters, J. W., Cofield, R. E., Cuddy, D. T., Daffer, W. H., Drouin, B. J., Fuller, R. A., Jarnot, R. F., Jiang, Y. B., Knosp, B. W., Li, Q. B., Perun, V. S., Schwartz, M. J., Snyder, W. V., Stek, P. C., Thurstans, R. P., Wagner, P. A., Avery, M., Browell, E. V., Cammas, J.P., Christensen, L. E., Diskin, G. S., Gao, R.-S., Jost, H.-J., Loewenstein, M., Lopez, J. D., Nedelec, P., Osterman, G. B., 
Sachse, G. W., and Webster, C. R.: Validation of Aura Microwave Limb Sounder O3 and CO observations in the upper troposphere and lower stratosphere, J. Geophys. Res.-Atmos., 113, D15S02, doi:10.1029/2007JD008805, 2008.

Livesey, N. J., Read, W. G., Froidevaux, L., Lambert, A., Manney, G. L., Pumphrey, H. C., Santee, M. L., Schwartz, M. J., Wang, S., Cofield, R. E., Cuddy, D. T., Fuller, R. A., Jarnot, R. F., Jiang, J. H., Knosp, B. W., Stek, P. C., Wagner, P. A., and Wu, D. L.: Version 3.3 and 3.4 Level 2 data quality and description document, Tech. Rep. JPL D-33509, NASA Jet Propulsion Laboratory, version 3.3x/3.4x-1.1, 2013.

Livesey, N. J., Read, W. G., Wagner, P. A., Froidevaux, L., Lambert, A., Manney, G. L., Millán-Valle, L. F., Pumphrey, H. C., Santee, M. L., Schwartz, M. J., Wang, S., Fuller, R. A., Jarnot, R. F., Knosp, B. W., and Martinez, E.: Version 4.2x Level 2 data quality and description document, Tech. Rep. JPL D-33509, NASA Jet Propulsion Laboratory, version 4.2x-1.0, 2015.

Manabe, S. and Wetherald, R. T.: Thermal equilibrium of the atmosphere with a given distribution of relative humidity, J. Atmos. Sci., 24, 241-259, 1967.

Nash, J., Oakley, T., Vömel, H., and Li, W.: WMO intercomparison of high quality radiosonde systems, Yangjiang, China, 12 July3 August 2010, Instruments and Observing Methods Report No. 107, WMO/TD-No. 1580, 238 pp., 2011.

Park, M., Randel, W. J., Gettelman, A., Massie, S. T., and Jiang, J. H.: Transport above the Asian summer monsoon anticyclone inferred from Aura Microwave Limb Sounder tracers, J. Geophys. Res.-Atmos., 112, D16309, doi:10.1029/2006JD008294, 2007.

Ploeger, F., Günther, G., Konopka, P., Fueglistaler, S., Müller, R., Hoppe, C., Kunz, A., Spang, R., Grooß, J.-U., and Riese, M.: Horizontal water vapor transport in the lower stratosphere from subtropics to high latitudes during boreal summer, J. Geophys. Res.-Atmos., 118, 8111-8127, doi:10.1002/jgrd.50636, 2013.

Randel, W. J. and Park, M.: Deep convective influence on the Asian summer monsoon anticyclone and associated tracer variability observed with Atmospheric Infrared Sounder (AIRS), J. Geophys. Res.-Atmos., 111, D12314, doi:10.1029/2005JD006490, 2006

Randel, W. J., Park, M., Emmons, L., Kinnison, D., Bernath, P., Walker, K. A., Boone, C., and Pumphrey, H.: Asian monsoon transport of pollution to the stratosphere, Science, 328, 611-613, doi:10.1126/science.1182274, 2010.

Read, W. G., Shippony, Z., Schwartz, M. J., Livesey, N. J., and Snyder, W. V.: The clear-sky unpolarized forward model for the EOS Aura Microwave Limb Sounder (MLS), IEEE T. Geosci. Remote Sens., 44, 1367-1379, 2006.

Read, W. G., Lambert, A., Bacmeister, J., Cofield, R. E., Christensen, L. E., Cuddy, D. T., Daffer, W. H., Drouin, B. J., Fetzer, E., Froidevaux, L., Fuller, R., Herman, R., Jarnot, R. F., Jiang, J. H., Jiang, Y. B., Kelly, K., Knosp, B. W., Kovalenko, L. J., Livesey, N. J., Liu, H. C., Manney, G. L., Pickett, H. M., Pumphrey, H. C., Rosenlof, K. H., Sabounchi, X., Santee, M. L., Schwartz, M. J., Snyder, W. V., Stek, P. C., Su, H., Takacs, L. L., Thurstans, R. P., Vömel, H., Wagner, P. A., Waters, J. W., Webster, C. R., Weinstock, E. M., and Wu, D. L.: Aura Microwave Limb Sounder upper tropospheric and lower stratospheric $\mathrm{H}_{2} \mathrm{O}$ and relative humidity with respect to ice validation, J. Geophys. Res.-Atmos., 112, D24S35, doi:10.1029/2007JD008752, 2007.
Rodgers, C. D.: Retrieval of atmospheric temperature and composition from remote measurements of thermal radiation, Rev. Geophys., 14, 609-624, 1976.

Rodgers, C. D.: Inverse Methods for Atmospheric Sounding: Theory and Practice, World Scientific Publishing, Singapore, 2000.

Schwartz, M. J., Lambert, A., Manney, G. L., Read, W. G., Livesey, N. J., Froidevaux, L., Ao, C. O., Bernath, P. F., Boone, C. D., Cofield, R. E., Daffer, W. H., Drouin, B. J., Fetzer, E. J., Fuller, R. A., Jarnot, R. F., Jiang, J. H., Jiang, Y. B., Knosp, B. W., Krüger, K., Li, J. L. F., Mlynczak, M. G., Pawson, S., Russell III, J. M., Santee, M. L., Snyder, W. V., Stek, P. C., Thurstans, R. P., Tompkins, A. M., Wagner, P. A., Walker, K. A., Waters, J. W., and $\mathrm{Wu}, \mathrm{D}$. L.: Validation of the Aura Microwave Limb Sounder temperature and geopotential height measurements, J. Geophys. Res.-Atmos., 113, D15S11, doi:10.1029/2007JD008783, 2008.

Smit, H. G. J., Straeter, W., Johnson, B. J., Oltmans, S. J., Davies, J., Tarasick, D. W., Hoegger, B., Stubi, R., Schmidlin, F. J., Northam, T., Thompson, A. M., Witte, J. C., Boyd, I., and Posny, F.: Assessment of the performance of ECC ozonesondes under quasi-flight conditions in the environmental simulation chamber: Insights from the Juelich Ozone Sonde Intercomparison Experiment (JOSIE), J. Geophys. Res.-Atmos., 112, D19306, doi:10.1029/2006JD007308, 2007.

Soden, B. J., Held, I. M., Colman, R., Shell, K. M., Kiehl, J. T., and Shields, C. A.: Quantifying climate feedbacks using radiative kernels, J. Climate, 21, 3504-3520, doi:10.1175/2007JCLI2110.1, 2008.

Solomon, S., Rosenlof, K. H., Portmann, R. W., Daniel, J. S., Davis, S. M., Sanford, T. J., and Plattner, G.-K.: Contributions of stratospheric water vapor to decadal changes in the rate of global warming, Science, 327, 1219-1223, 2010.

Tegtmeier, S., Hegglin, M. I., Anderson, J., Bourassa, A., Brohede, S., Degenstein, D., Froidevaux, L., Fuller, R., Funke, B., Gille, J., Jones, A., Kasai, Y., Krüger, K., Kyrölä, E., Lingenfelser, G., Lumpe, J., Nardi, B., Neu, J., Pendlebury, D., Remsberg, E., Rozanov, A., Smith, L., Toohey, M., Urban, J., von Clarmann, T., Walker, K. A., and Wang, R. H. J.: SPARC Data Initiative: A comparison of ozone climatologies from international satellite limb sounders, J. Geophys. Res.-Atmos., 118, 12,229-12,247, doi:10.1002/2013JD019877, 2013.

Tobo, Y., Iwasaka, Y., Zhang, D., Shi, G., Kim, Y.-S., Tamura, K., and Ohashi, T.: Summertime "ozone valley" over the Tibetan Plateau derived from ozonesondes and EP/TOMS data, Geophys. Res. Lett., 35, L16801, doi:10.1029/2008GL034341, 2008.

Uma, K. N., Das, S., and Das, S.: A climatological perspective of water vapor at the UTLS region over different global monsoon regions: observations inferred from the Aura-MLS and reanalysis data, Clim. Dynam., 43, 407-420, doi:10.1007/s00382-0142085-9, 2014.

Vömel, H., Barnes, J. E., Forno, R. N., Fujiwara, M., Hasebe, F., Iwasaki, S., Kivi, R., Komala, N., Kyrö, E., Leblanc, T., Morel, B., Ogino, S. Y., Read, W. G., Ryan, S. C., Saraspriya, S., Selkirk, H., Shiotani, M., Canossa, J. V., and Whiteman, D. N.: Validation of Aura Microwave Limb Sounder water vapor by balloonborne Cryogenic Frost point Hygrometer measurements, J. Geophys. Res.-Atmos., 112, D24S37, doi:10.1029/2007JD008698, 2007a.

Vömel, H., David, D. E., and Smith, K.: Accuracy of tropospheric and stratospheric water vapor measurements by the cryogenic frost point hygrometer: Instrumental details 
and observations, J. Geophys. Res. Atmos., 112, D08305, doi:10.1029/2006JD007224, 2007b.

Waters, J. W., Froidevaux, L., Harwood, R. S., Jarnot, R. F., Pickett, H. M., Read, W. G., Siegel, P. H., Cofield, R. E., Filipiak, M. J., Flower, D. A., Holden, J. R., Lau, G. K., Livesey, N. J., Manney, G. L., Pumphrey, H. C., Santee, M. L., Wu, D. L., Cuddy, D. T., Lay, R. R., Loo, M. S., Perun, V. S., Schwartz, M. J., Stek, P. C., Thurstans, R. P., Boyles, M. A., Chandra, K. M., Chavez, M. C., Chen, G.-S., Chudasama, B. V., Dodge, R., Fuller, R. A., Girard, M. A., Jiang, J. H., Jiang, Y., Knosp, B. W., LaBelle, R. C., Lam, J. C., Lee, K. A., Miller, D., Oswald, J. E., Patel, N. C., Pukala, D. M., Quintero, O., Scaff, D. M., Snyder, W. V., Tope, M. C., Wagner, P. A., and Walch, M. J.: The Earth Observing System Microwave Limb Sounder (EOS MLS) on the Aura Satellite, IEEE T. Geosci. Remote Sens., 44, 1075-1092, 2006.
Wright, J. S., Fu, R., Fueglistaler, S., Liu, Y. S., and Zhang, Y.: The influence of summertime convection over Southeast Asia on water vapor in the tropical stratosphere, J. Geophys. Res.-Atmos., 116, D12302, doi:10.1029/2010JD015416, 2011.

Xu, X., Lu, C., Shi, X., and Gao, S.: World water tower: An atmospheric perspective, Geophys. Res. Lett., 35, L20815, doi:10.1029/2008GL03586, 2008.

Yan, X., Zheng, X., Zhou, X., Vömel, H., Song, J., Li, W., Ma, Y., and Zhang, Y.: Validation of Aura Microwave Limb Sounder water vapor and ozone profiles over the Tibetan Plateau and its adjacent region during boreal summer, Sci. China Ser. D, 58, 589603, doi:10.1007/s11430-014-5014-1, 2015.

Zhou, X. J., Luo, C., Li, W. L., and Shi, J. E.: Variations of total ozone amount in China and the ozone low center over Tibetan Plateau, China Sci. Bull., 40, 1396-1398, 1995 (in Chinese). 